\title{
Intertidal ecosystem engineer species promote benthic- pelagic coupling and diversify trophic pathways
}

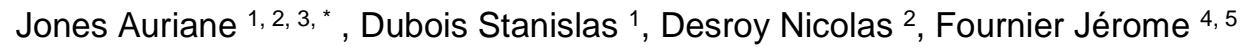

1 IFREMER, Lab Ecol Benth Cotiere LEBCO, DYNECO, Ctr Bretagne, F-29280 Plouzane, France.

2 IFREMER, Lab Environm \& Ressources Bretagne Nord, F-35801 Dinard, France.

3 INRAE, ESE, Agrocampus Ouest, Ecol \& Ecosyst Hlth, F-35042 Rennes, France.

${ }^{4}$ CNRS, UMR 7204 CESCO, F-75005 Paris, France.

${ }^{5}$ MNHN, Stn Biol Marine, F-29182 Concarneau, France.

*Corresponding author : Auriane G. Jones, email address : jones.ecology@gmail.com

\begin{abstract}
:
Ecosystem engineering is a ubiquitous process by which the biological activity of a species shapes habitat diversity and often creates local biodiversity hotspots. The honeycomb-worm Sabellaria alveolata, an intertidal ecosystem engineer, actively builds reefs across Europe by aggregating sand. Here, we used carbon and nitrogen isotopic compositions measured on basal resources and bentho-demersal consumers (fish, mega- and macroinvertebrates) to empirically investigate how non-trophic interactions (ecosystem engineering) modify food web structure and functioning. Three sediment types corresponding to different substrata and species assemblages were sampled: a control soft sediment (medium to muddy sand, before the establishment of S. alveolata), the sediment engineered by S. alveolata (hardened 3D structures), and the soft sediment under the influence of S. alveolata (associated sediment). Using consumer community isotopic biplots (biomass-weighted), niche metrics (standard ellipse area), and mixing models, we found that $\mathrm{S}$. alveolata, through the physical structure it creates, the stimulation of basal resources (microphytobenthos and Ulva), and the diversification of suspension-feeding species, promotes benthic-pelagic coupling and a habitat-wide form of 'gardening,' which further leads to trophic pathway diversification and limits trophic competition between the engineer species and associated suspension-feeders. Furthermore, our results help to refine the definition of $\mathrm{S}$. alveolata reefs as the sum of the engineered and associated sediments since they are part of a single reef food web coupled by the stimulated basal resources and consumers. Finally, the non-trophic and trophic interactions mediated by S. alveolata and the associated macrofauna seem to promote the establishment of a temporally stable and probably highly resilient reef habitat.
\end{abstract}

Keywords: Stable isotopes, Food web, Gardening hypothesis, Non-trophic interactions, Microphytobenthos, Suspension-feeding, Habitat modifier 


\section{INTRODUCTION}

The study of landscapes, either terrestrial or aquatic, has long investigated habitat diversity and its underlying drivers (McGarigal et al. 2012), classically focusing on environmental factors like geomorphology and physical disturbance (Stallins 2006). Yet organisms themselves can also be at the origin of habitat diversity through their biological activity, as first conceptualized by Jones et al. (1994). These species are termed ecosystem engineers, a concept regrouping organisms able to directly or indirectly modulate the availability of resources to other species by modifying the physical properties of abiotic material (e.g. sediment, soil) or biotic material (e.g. trees in the case of beavers (Wright et al. 2002)). Ultimately, these organisms can modify, maintain, and create habitats, often leading to changes in species assemblages and the creation of biodiversity hotspots (Jones et al. 1997, Romero et al. 2015). Physical ecosystem engineers, also known as habitat modifiers (van der Zee et al. 2016), are particularly present in stressful environments like terrestrial deserts and intertidal zones where they create new habitats characterized by less extreme environmental conditions (Jones et al. 1997, Romero et al. 2015). Many such habitat-building ecosystem engineers are present along temperate coasts: autotrophs like cordgrass (e.g. Spartina spp.), seagrass (e.g. Zostera marina) and macroalgae (e.g. Laminaria hyperborea), reef-building heterotrophs like mussels (e.g. Mytilus edulis), oysters (e.g. Crassostrea virginica), tube-building polychaetes (e.g. Lanice conchilega, Phragmatopoma caudata) and gastropods (e.g. Dendropoma petraeum) (Gutiérrez et al. 2012, Goldberg 2013).

Ecosystem engineering was first based only on relatively complex non-trophic interactions, conceived in opposition to direct interactions such as predator-prey or plant-pollinator interactions (Jones et al. 1994). Indeed, the ecosystem engineer was not considered according to its trophic role or position but as a promoter of new community-wide interactions through a series of structural, abiotic, and biotic changes and associated feedbacks (Jones et al. 2010). Consequently, the ecosystem engineer concept has only recently been integrated in theoretical and empirical food web studies (Sanders et al. 2014, De Smet 
et al. 2015, van der Zee et al. 2016), despite the ubiquity of ecosystem engineers and the potentially broad-scale conclusions such a coupling could foster. Theoretically, an ecosystem engineer able to modify consumable abiotic resources like nutrients could stimulate primary producer diversity and abundance, which could then modify the properties of the entire food web (Layman et al. 2007, Sanders et al. 2014, van der Zee et al. 2016). For example, higher producer diversity can lead to trophic pathway diversification, consumer niche differentiation, and ultimately to larger community-wide trophic niches and to more stable food webs (Zhao et al. 2019), therefore coupling non-trophic (ecosystem engineering) and trophic interactions.

Coastal reef-building polychaetes and mollusks (i.e. structural ecosystem engineers, Berke (2010)) can locally increase the biomass of benthic microalgae through the structures they build, the resulting abiotic changes and their biological activity (Echappé et al. 2017, Engel et al. 2017, Jones et al. 2018, Bruschetti 2019) and the resulting reefs can serve as support for various macroalgae (e.g. Ulva spp., Ceramium sp.) (Vizzini et al. 2012, Dubois \& Colombo 2014). Ultimately, many coastal reefbuilding engineer species (e.g. Mytilus edulis, Magallana gigas, Dendropoma petraeum, Ficopomatus enigmaticus, Sabellaria alveolata) diversify basal trophic resources (higher producer diversity and biomass). Several questions emerge from the producer diversification associated with ecosystem engineering: Is this higher producer diversity associated with larger community-wide trophic niches and primary consumer niche differentiation? How important are these stimulated basal trophic resources in fueling the food web? In this article, we investigated these questions using the intertidal ecosystem engineer Sabellaria alveolata as a case study. Overall, our aim was to understand how structural ecosystem engineers (Berke 2010) like Sabellaria alveolata, affect food web structure and functioning, focusing on littoral organic matter transfers and primary consumers.

Sabellaria alveolata, the honeycomb-worm, is a gregarious intertidal polychaete, commonly found along the European coastline from Scotland and Ireland to Morocco (Muir et al. 2016). This 
sedentary polychaete lives in a tube made with bioclastic sand particles glued together with an organic cement (Le Cam et al. 2011, Buffet et al. 2018). Through the building of these tubes, this species transforms soft sediments into three-dimensional hard structures (engineered sediments), forming a new habitat (Dubois et al. 2002, Bruschetti 2019). These hard structures, called reefs, are fixed atop rocks, pebbles, and in rarer cases are present exclusively in soft sedimentary areas, covering surfaces from a few square meters to dozens of hectares (Holt et al. 1998, Desroy et al. 2011) and ultimately building the largest intertidal bioconstructions in Europe (Noernberg et al. 2010). Sabellaria alveolata leads to the establishment of two distinct macrobenthic assemblages in the engineered sediments and in the soft sediments under its influence (associated sediments); both assemblages differ from those macrobenthic communities characterizing the soft sediments outside the reef's influence (control sediments). The engineered sediment community presents the highest species richness and is characterized by an original assemblage of species typically found on rocky shores (e.g. Perinereis cultrifera, Steromphala spp., Porcellana platycheles), in sandy to muddy sediments (e.g. Glycera alba, Mediomastus fragilis, Corophium volutator) and even on land (Axelsonia littoralis, Hydrogamasus sp.) (Jones et al. 2018).

Through its engineering properties, S. alveolata also affects two basal trophic resources: microphytobenthos (MPB) biomass and the presence of green macroalgae (Ulva spp.). Indeed, the MPB biomass increases in the presence of this ecosystem engineer, as shown by comparing the associated sediments with the control sediments (Jones et al. 2018). Once resuspended by tidal currents, this stimulated basal trophic resource can become available to the engineered sediment associated fauna including the engineer species (Dubois et al. 2007, Ubertini et al. 2012). Green macroalgae from the genus Ulva also grow on the engineered sediments (Dubois et al. 2006), representing an additional basal trophic resource, directly consumable by grazers and indirectly consumable by suspension- and depositfeeders once detached and fragmented (Hondula \& Pace 2014, Dubois \& Colombo 2014). Consequently, two additional questions arise. Are the stimulated basal trophic resources, MPB and Ulva spp., consumed 
by the ecosystem engineer, as evidenced in the gardening hypothesis (Hylleberg 1975)? This hypothesis was first developped for the lugworm Abarenicola pacifica, which stimulates microbes naturally present around its burrow, via its digestion and the production of feces, and then consumes these stimulated microbes. A second question extends this gardening hypothesis to other primary consumers associated with the engineer species and paves the way to a potential habitat-wide form of gardening, as previsouly shown for the tubiculous amphipod Haploops nirae (Rigolet et al. 2014).

To answer the aforementioned questions, we sampled extensively the consumers (macro and megafauna) and potential basal resources present in the previously defined engineered, associated and control sediments, and measured their carbon and nitrogen isotopic compositions (Majdi et al. 2018). We first focused on the consumer community and compared the food web structure (biomass distribution and isotopic niche) of the three sediment type communities. Then, we estimated the relative importance of local benthic basal resources (i.e. MPB and Ulva spp.) in fueling each food web, by focusing on the primary consumer trophic level and in line with the gardening hypothesis. We hypothesized that the engineered and associated sediment communities (H1) would show wider isotopic niches than the control sediment community and (H2) would rely more on local benthic basal resources (i.e. MPB and Ulva spp.) than the control sediment community (i.e. only MPB) because of the additional resources stimulated by $S$. alveolata through reef engineering. We also estimated the assimilated diet of the engineer species along with four associated and abundant suspension-feeding species, to further investigate the gardening hypothesis and the potential inter-specific trophic niche differentiation (Dubois et al. 2007, Dubois \& Colombo 2014) in the very densely populated engineered sediment (Jones et al. 2018). Finally, to get a sense of the temporal variability in the food web structure and functioning of each sediment type, we sampled the consumers in late February and mid-September, two highly contrasted times of the year in terms of phytoplankton productivity (low vs high), abundance of basal trophic resources (low vs high) 
and benthic community dynamics (pre and post-recruitment) (Marín Leal et al. 2008, Cugier et al. 2010, Ubertini et al. 2012).

\section{MATERIAL \& METHODS}

\subsection{Study sites}

This study was conducted in the Mont-Saint-Michel Bay, a semi-diurnal macrotidal bay (14 m maximal tidal range) with an extensive intertidal zone $\left(250 \mathrm{~km}^{2}\right)$, located in the western part of the English Channel (France) (Bonnot-Courtois et al. 2002). The central area of the bay where are located our two study sites, is at the junction of two tidal current regimes, a western gyre turning clockwise and an eastern current alternating north-south (Salomon \& Breton 1991, Bonnot-Courtois et al. 2002). Our first study site was the Sainte-Anne reef (i.e. reef site, $48^{\circ} 38^{\prime} 700 \mathrm{~N}$ and $1^{\circ} 40^{\prime} 100 \mathrm{~W}$ ), the largest bioconstruction in Europe (Holt et al. 1998, Noernberg et al. 2010). This $2.5 \mathrm{~km}$ in length by $1 \mathrm{~km}$ in width site spreads parallel to the coast and is composed of the previously defined engineered sediments and associated sediments, the ES representing ca. 32 ha in 2014 (A. Jones unpubl. data).

We defined a second study site as the control site, hereafter denoted as the control sediments (CS). This 24 ha soft sediment zone was outside the reef's influence (1.5 km northeast of the reef), on the same bathymetric level as the reef (i.e. between the -2 and $-4 \mathrm{~m}$ isobaths, Noernberg et al. (2010), characterized by medium to muddy sands (Bonnot-Courtois et al. 2009) and by a species-poor community typified by the bivalve Limecola balthica (formerly Macoma balthica) (Dubois et al. 2002). This site did not present any hard structures such as rocks or boulders. We considered the CS as representing the local soft sediments before the establishment of the Sainte-Anne reef and before the combined physical and biological effects of the reef and its associated organisms on the local trophodynamics. Indeed, these two effects cannot be separated since a reef structure without any live Sabellaria 
alveolata worms and their building activity degrades and disappears after a few years (Gruet 1972, Wilson 1976).

\subsection{Sample collection and preparation for consumer stable isotope analyses}

\subsubsection{Over-dispersed macrofauna and infauna sampling}

For the macrofauna, we randomly sampled ten stations in the two sediment types from the reef site (AS and ES) and in the sediment type from the control site (CS). Each station was separated by at least $75 \mathrm{~m}$. We sampled these 30 stations on foot during low spring tides, once in late February and once in mid-September 2015, hereafter referred to as winter and summer for a generalization purpose, to investigate the food web structure and functioning of the communities associated with each sediment type (CS, AS and ES) at two contrasted times of the year. Indeed, winter is characterized by a low abundance of basal trophic resources, whereas in late summer, benthic and pelagic basal resources are more abundant and benthic invertebrates have recruited (Marín Leal et al. 2008, Cugier et al. 2010, Ubertini et al. 2012).

Over-dispersed macrofauna - mostly mollusk species - were sampled using a $1 \mathrm{~m}^{2}$ quadrat with three replicates per station. For the AS and CS quadrat sampling, the first $5 \mathrm{~cm}$ of soft sediment was sieved through a 5-mm square mesh, while for the ES quadrat sampling, we hand-collected all the visible macrofauna located on the reef and inside the reef interstices within the area of the $1 \mathrm{~m}^{2}$ quadrat. Infauna and smaller macrofauna organisms were sampled using an $18.5 \mathrm{~cm}$ side corer ( to a depth of $15 \mathrm{~cm}$ with one replicate per station. To sample the CS and AS, we used a mainstream hand corer for soft sediments and sieved on site the soft sediment cores through a 1-mm square mesh. The resulting sediments were sorted back at the lab. To sample the hardened ES (i.e. reef material), we used a specially designed metal hand corer with teeth. The ES cores were taken back to the lab where they were broken apart under water and the organisms retained on a 1-mm square mesh were collected. 
Finally, all the collected organisms were identified to the lowest taxonomic level (generally the species level) and stored at $-20^{\circ} \mathrm{C}$ for stable isotope analyses.

\subsubsection{Vagile macro and megafauna sampling}

Vagile benthic and demersal macro and megafauna organisms were sampled at the site scale (and not at the sediment type scale) using traditional set nets from the Mont-Saint-Michel Bay, which are like fyke nets but without wings (Secula 2011). In the control and reef sites, six nets were positioned on foot at low tide, once in early March 2015 and once in mid-September 2015, with their opening landward and left to fish for two consecutive tidal cycles $(24 \mathrm{~h})$. Back at the lab, all the organisms were sorted, identified to the lowest taxonomic level (generally the species level) and finally stored at $-20^{\circ} \mathrm{C}$ for stable isotope analyses.

\subsubsection{Sample preparation}

For the fish, mollusks, and shrimps, we dissected muscle tissue. For smaller species (e.g. polychaetes), we used the whole body, and removed the guts when possible. For very small species (e.g. Collembola), we pooled several individuals to meet the minimum required weight for stable isotope analyses. For calcified organisms (crustaceans other than shrimp and echinoderms), a subsample was acidified $(10 \% \mathrm{HCl})$ to remove any inorganic carbonates and then used to determine the carbon isotopic composition, while a subsample was left untreated for the nitrogen isotopic composition. All the samples were then rinsed with Milli-Q water and freeze-dried. Each animal sample was ground to a homogeneous powder and $1 \mathrm{mg}$ was encapsulated. When possible, at least three replicates per species and per station were analyzed. We used ultra-clean light tin capsules for all the samples (consumers and organic matter sources).

\subsection{Sample collection and preparation for organic matter source stable isotope analyses}


We sampled the different basal trophic resources every month over a period of one year (January 2015 to January 2016) to consider the temporal variability of their respective isotopic composition. At the control site (CS), the organic matter available to primary consumers was mainly composed of marine suspended particulate organic matter (POM; mainly phytoplankton) and of microphytobenthos (MPB). At the reef site (AS and ES), green macroalgae (Ulva spp., ULV) growing on the ES was considered as a third potential basal resource. We verified a posteriori that the sediment organic matter (SOM) was a mixture of the two or three aforementioned basal resources. In the two study sites, the riverine terrestrial inputs of organic matter are extremely limited and as such, were not considered as a potential basal resource (Riera 2007).

\subsubsection{Marine suspended particulate organic matter}

For POM, marine subsurface water ( $1 \mathrm{~m}$ below the surface) was collected just before high tide using a Niskin bottle and at one sampling point seaward of the reef site. We considered POM as being distributed homogeneously between our two study sites based on the tidal regimes (see part 2.1) and the strong tidal currents $\left(0.4-1.5 \mathrm{~m} . \mathrm{s}^{-1}\right)$ characterizing the zone of the Mont-Saint-Michel Bay where both sites are located (Salomon \& Breton 1991, Bonnot-Courtois et al. 2002). Consequently, we considered POM to have similar isotopic compositions in the reef and control sites (Ayata et al. 2009). Back at the lab, water samples were prefiltered on a $200 \mu \mathrm{m}$ square mesh to remove macrodetritus and zooplankton (Marín Leal et al. 2008), then filtered on three precombusted $\mathrm{GF} / \mathrm{F}$ filters $\left(4 \mathrm{~h}, 450^{\circ} \mathrm{C}\right)$ and finally rinsed with Milli-Q water (three replicates per month). The filters were freeze-dried, and half of each filter was acidified for $48 \mathrm{~h}$ with $32 \mathrm{M} \mathrm{HCl}$ fumes to remove any traces of inorganic carbonates (Lorrain et al. 2003), before being oven dried at $30^{\circ} \mathrm{C}$. Then, every half filter was scraped with a clean scalpel, ground to a homogeneous powder and $10 \mathrm{mg}$ of the powder was encapsulated for stable isotope analyses. The non-acidified samples were used to determine the nitrogen isotopic compositions while the acidified ones were used for the carbon isotopic compositions. 
2.3.2. Microphytobenthos, sediment organic matter and Ulva spp.

Microphytobenthos, SOM and ULV were sampled on foot during low spring tides. For MPB and SOM, the first centimeter of the AS was sampled, using a $1-\mathrm{cm}$ high plastic petri dish $\left(57 \mathrm{~cm}^{2}\right)$, at two points inside the reef site (six replicates per month). For ULV, green macroalgae (Ulva spp.) was collected from the ES within a $10 \mathrm{~m}$ radius of the same two previously mentioned points in the reef (two replicates per month). All the samples were kept at $-20^{\circ} \mathrm{C}$ for stable isotope analyses. To extract the MPB from the sediment, we followed the protocol in Marín Leal et al. (2008), which is a modified version of Blanchard et al. (1988) (Electronic supplement S1). The extracted MPB was freeze-dried, ground to a homogeneous powder, and $1 \mathrm{mg}$ of powder was encapsulated. For the SOM analyses, a sediment subsample was acidified $(10 \% \mathrm{HCl})$ to remove inorganic carbonates and rinsed with Milli-Q water, while the rest was left untreated. All the material was then freeze-dried, and $40 \mathrm{mg}$ of sediment was encapsulated. The nonacidified samples were used to determine the nitrogen isotopic compositions while the acidified ones were used for the carbon isotopic compositions. For the ULV analyses, epibionts were scraped off the green algae fragments using a clean scalpel. Then, the clean algae fragments were rinsed with Milli-Q water, freeze-dried, and finally ground to a homogeneous powder, $3 \mathrm{mg}$ of which was encapsulated.

\subsection{Stable isotope analyses and data preparation}

Carbon and nitrogen isotopic compositions were measured with a Thermo Delta V isotope mass spectrometer coupled via a Conflo IV to a Carlo Erba NC2500 elemental analyzer (Cornell University Stable Isotope Laboratory). Isotope ratios of carbon and nitrogen were reported using the standard $\delta$ notation as units of parts per thousand $(\%)$ relative to the international reference standards:

$$
\delta \mathrm{X}=\left[\left(\mathrm{R}_{\text {sample }} / \mathrm{R}_{\text {reference }}\right)-1\right] \times 1000
$$


where $\mathrm{X}={ }^{13} \mathrm{C}$ or ${ }^{15} \mathrm{~N}$, and $\mathrm{R}={ }^{13} \mathrm{C} /{ }^{12} \mathrm{C}$ for carbon and ${ }^{15} \mathrm{~N} /{ }^{14} \mathrm{~N}$ for nitrogen. Vienna Pee Dee Belemnite limestone and atmospheric nitrogen were used as reference standards for carbon and nitrogen, respectively. The analytical precision was $0.09 \%$ for both isotopes.

The biomass (wet weight) by $\mathrm{m}^{2}$ of the species sampled across the cores and quadrats was estimated using the catch-per-unit-effort (CPUE) method, i.e. the ratio between the total catch biomass and the total amount of effort to harvest the catch biomass (Jones et al. 2018). If a species was collected by only one sampling method, its biomass per $\mathrm{m}^{2}$ was estimated using the corresponding sampling surface $\left(1 \mathrm{~m}^{2}\right.$ for the quadrats and $269 \mathrm{~cm}^{2}$ for the cores). For the 17 species in winter and 15 species in summer sampled by both methods, their biomass per $\mathrm{m}^{2}$ was calculated using the cumulated biomasses divided by the sum of each equipment's CPUE (1.0269 $\mathrm{m}^{2}$ ) (Jones et al. 2018). In order to jointly consider the species sampled by the cores and/or quadrats and by the set nets, we estimated the instantaneous mean sediment surface sampled by the nets $\left(\mathrm{S}\right.$ in $\left.\mathrm{m}^{2}\right)$ using the annual mean bottom current speeds for the area $(\mathrm{v}=0.188$ m.s- 1 in 2015) extracted from the $500 \mathrm{~m}$ resolution MARS3D-AGRIF model (Caillaud et al. 2016), the mean width of the set nets $(\mathrm{w}=1.45 \mathrm{~m})$ and the mean fishing time of each net $(\mathrm{t}=7 \mathrm{~h})$. Using the following formula, $\mathrm{S}=\mathrm{v} \times \mathrm{w} \times \mathrm{t} \times 3600$, we estimated $\mathrm{S}$ as $6869 \mathrm{~m}^{2}$ and used it to calculate the biomass per $\mathrm{m}^{2}$ of the sampled species. Based on the biomass per $\mathrm{m}^{2}$ estimated with the cores, the quadrats and the set nets, we calculated the mean relative contribution of each species to the total biomass of the CS, AS and ES communities in winter and summer.

The monthly basal resource sampling was used to calculate the mean $\delta^{13} \mathrm{C}$ and $\delta^{15} \mathrm{~N}$ (and associated standard deviations) of the POM, SOM, MPB and ULV, which is displayed on the isotopic biplots (Fig. 1) and used in the Bayesian mixing models. All the January to March and October to January (2016) MPB samples (plus two April replicates and one August replicate) could not be considered because the quantity of MPB extracted was too low to allow a clean signal. All the March, May, and July to September POM samples (plus two January 2016 replicates) were not considered because of 
abnormally high $\delta^{13} \mathrm{C}$ values (>-15\%). All the November and December 2015 ULV samples were not considered because of abnormally low $\delta^{15} \mathrm{~N}$ values $(<4 \%$ ). Finally, one May, two August and one January 2016 SOM sample were not considered either because of abnormally high $\delta^{13} \mathrm{C}$ values $(>12.5 \%$ o) or low $\delta^{15} \mathrm{~N}(<4 \%)$.

Finally, the mean $\delta^{13} \mathrm{C}$ and $\delta^{15} \mathrm{~N}$ of the megafauna species sampled using the set nets deployed in the reef site were displayed on both the AS and ES isotopic biplots (Fig. 1) and we applied a correction factor to all the $C$. fornicata isotopic compositions as recent observations revealed calcium carbonate nodules in the muscular foot of C. fornicata (Androuin et al. 2019).

\subsection{Data analyses}

First, to estimate the overall width of each community food web (CS, AS and ES), we calculated several community-wide metrics based on the mean consumer $\delta^{13} \mathrm{C}$ and $\delta^{15} \mathrm{~N}$ values, using the "siar" (Parnell \& Jackson 2013) and "SIBER" (Jackson et al. 2011) packages developed in R (R Core Team 2018). The total area of the convex hull (TA), which encompasses all the consumer isotopic compositions (Layman et al. 2007), was first calculated to account for the overall trophic niche space occupied by each consumer community. The major drawback of the TA is its high sensitivity to extreme isotopic compositions (Brind'Amour \& Dubois 2013). In order to limit this bias, we also calculated the standard ellipse area (SEA), which only encompasses $40 \%$ of the data, and a Bayesian estimate of this metric (SEA ${ }_{B}$ ) to account for the uncertainty in the isotopic compositions (Jackson et al. 2011). To compare the size of two SEAs (between sediment types or between sampling times), we considered their respective Bayesian posterior distributions and calculated the probability that one SEA is smaller than another. Finally, we calculated the percent overlap between two isotopic niches (SEA) in relation to the surface of the smallest ellipse (\%). 
Pelagic organic matter, MPB and ULV differ in their respective $\delta^{13} \mathrm{C}$ and $\delta^{15} \mathrm{~N}$ values (Riera 2007, Dubois \& Colombo 2014) and this isotopic dissimilarity is passed on to the primary consumers relying on each basal resource. Species reported in the literature (Fauchald \& Jumars 1979, Navarro-Barranco et al. 2013, Guerra-García et al. 2014, Jumars et al. 2015) or in online biological trait databases (BIOTIC, WORMS) as being strictly suspension-feeders and/or deposit-feeders and/or grazers were considered here as primary consumers. To evaluate the importance of the different basal resources in fueling each food web, we plotted the frequency distribution of the $\delta^{13} \mathrm{C}$ and $\delta^{15} \mathrm{~N}$ values of all the primary consumers sampled in the three sediment types.

Finally, to quantify the relative contributions of pelagic (POM) and benthic basal resources (MPB in the CS community, MPB and ULV in the AS and ES communities) to a species' assimilated diet in winter and summer, Bayesian mixing models based on Markov chain Monte Carlo (MCMC) were implemented using the "simmr" package in R (Parnell 2016). This method works by repeatedly guessing the values of the dietary proportions and finding the values closest to the actual data. The best estimates of dietary proportions, given the data and the model, compose the posterior distribution (Parnell et al. 2013). The mixing model was set with no a priori basal resource contribution (uninformative prior), using two tracers $\left(\delta^{13} \mathrm{C}\right.$ and $\left.\delta^{15} \mathrm{~N}\right)$ and considering two (POM and MPB in the CS model) or three (POM, MPB and ULV in the AS and ES models) basal resources. We used the mean basal resource $\delta^{13} \mathrm{C}$ and $\delta^{15} \mathrm{~N}$ values and their associated standard deviations presented in section 2.4. To run the mixing models, a priori estimates of the variation in the isotopic compositions between the basal resources and consumers is required, which are termed the trophic discrimination factors (TDF). We considered a TDF between the basal resource and primary consumer of $1 \%$ and 3.4\%o for carbon and nitrogen respectively (McCutchan et al. 2003), with a standard deviation of 1 for both tracers. This high standard deviation was chosen to take into account the known variability in the TDFs linked to multiple factors such as food quality, tissue turnover, environmental conditions and taxonomic group (Vander Zanden \& Rasmussen 
2001, McCutchan et al. 2003, Vanderklift \& Ponsard 2003). Overall, we hypothesized that consumers were feeding ad libitum and had normal growth, hence having standard turnover rates for small invertebrates and standard TDFs (Lefebvre \& Dubois 2016).

Stable isotope mixing models (100,000 iterations, three chains) were implemented for each species known to feed at least partly on MPB, POM or ULV and for which we had at least three $\delta^{13} \mathrm{C}$ and $\delta^{15} \mathrm{~N}$ replicate values. We also implemented these models at the primary consumer scale by pooling the isotope compositions of all the primary consumers sampled in each community and at each sampling time. The $\delta^{13} \mathrm{C}$ and $\delta^{15} \mathrm{~N}$ values of some species were not located inside the space encompassing the two or three basal resources once corrected for the TDF (e.g. L. rugicauda in the summer AS, Fig. 1) or the number of replicates was sometimes limited (e.g. R. philippinarum, $\mathrm{n}=3$ in the winter ES, Table S3), leading to large uncertainties in the estimated dietary proportions. Using the stable isotope mixing model outputs, we also built ternary plots representing the relative contributions of POM, MPB and ULV to the assimilated diets of the five most abundant suspension-feeders of the ES. In these plots, each set of points represents the realized trophic niche of a species in winter or summer. The lack of replicates of the consumer community during each season (winter and summer) prevented us from being able to rigorously evaluate seasonal variations. Consequently, we only used our bi-annual sampling to get a sense of the similarities and differences in the food web structure and functioning of each sediment type between two contrasted productivity and recruitment regimes. We used R version 3.5.1.

\section{RESULTS}

\subsection{General structure of the consumer communities}

To start, we present the general community structure of each sediment type at both sampling times by considering their respective species diversity (by taxonomic class) and the dominant (biomass) species (Table 1). The CS and AS communities were characterized by a lower consumer richness than the ES. 
Polychaetes, followed by malacostraca crustaceans and bivalves were the most diversified taxonomic classes in the two soft-sediment communities whereas in the ES, gastropods were as diversified as the aforementioned taxonomic classes. Diversity patterns were different when considering only the strict primary consumers. In the CS and AS, first bivalves and then polychaetes were the most diversified taxonomic classes whereas in the ES, bivalves and gastropods were equally diversified (Table 1).

Two bivalves and one polychaete species dominated the CS consumer community, reflecting the primary consumer diversity structure. The cockle Cerastoderma edule and the Baltic tellin Limecola balthica, both suspension-feeders, alternately dominated the biomass in winter and summer, with the polychaete Lanice conchilega, also accounting for $7-15 \%$ of the biomass (Table 1). Conversely, in the AS, the gastropod Crepidula fornicata, reported to be mostly a suspension-feeder, accounted for 59-62\% of the total consumer biomass, followed by the deposit-feeding polychaete Cirriformia tentaculata (Table 1). Similarly to the consumer diversity structure, the ES consumer biomass was dominated by a polychaete, the suspension-feeding engineer species Sabellaria alveolata, a bivalve, the Japanese oyster Magallana gigas and a malacostraca crustacean, the porcellanid crab Porcellana platycheles (Table 1).

Overall, the patterns identified in each sediment type were quite similar in winter and summer with a change in the species dominating the CS and ES community biomass. In the CS, C. edule dominated in winter and L. balthica in summer and in the ES, S. alveolata dominated in winter and $M$. gigas dominated in summer (Table 1).

\subsection{Food web structure and consumer community isotopic niches}

Then, we move to the food web structure of each consumer community by focusing on the isotopic biplots (Fig. 1) and by comparing their respective isotopic niche widths in summer and winter (Fig. 2 and Table 2). The basal resources and macrofauna displayed an organization in the isotopic biplots characteristic of benthic intertidal communities with values constrained between -24 and $-13 \%$ on the 
$\delta^{13} \mathrm{C}$ axis and between 4 and $15 \%$ on the $\delta^{15} \mathrm{~N}$ axis. The benthic basal resources (MPB and ULV) had higher $\delta^{13} \mathrm{C}$ values than the pelagic resource (POM), and green macroalgae (ULV) had higher $\delta^{15} \mathrm{~N}$ values than MPB and POM. As hypothesized, SOM appeared graphically as a mixture of POM and MPB in the CS with the addition of ULV in the AS and ES (Fig. 1). The mean $\delta^{13} \mathrm{C}$ and $\delta^{15} \mathrm{~N} \pm \mathrm{SD}$ of the basal resources were $-22.92 \pm 1.31 \%$ o $\left(\delta^{13} \mathrm{C}\right)$ and $5.43 \pm 0.91 \%$ o $\left(\delta^{15} \mathrm{~N}\right)$ for POM, $-17.75 \pm 1.57 \%$ o $\left(\delta^{13} \mathrm{C}\right)$ and $5.54 \pm 0.55 \%$ o $\left(\delta^{15} \mathrm{~N}\right)$ for MPB, $-15.93 \pm 0.75 \%$ o $\left(\delta^{13} \mathrm{C}\right)$ and $8.93 \pm 0.85 \%$ o $\left(\delta^{15} \mathrm{~N}\right)$ for ULV and $-20.75 \pm$ $0.31 \%\left(\delta^{13} \mathrm{C}\right)$ and $6.94 \pm 0.27 \%$ o $\left(\delta^{15} \mathrm{~N}\right)$ for SOM.

These two or three basal resources supported the main primary consumers in the different sediment types except for Collembola (ES in summer), which displayed extreme isotopic compositions relative to the majority of species (Fig. 1 and Table S2) indicating that they probably rely on non-sampled basal resources with very high $\delta^{13} \mathrm{C}$ values (e.g. cyanobacteria). The total area of the consumer convex hull (TA) was driven by species showing extreme isotopic compositions, such as Lekanesphaera rugicauda in the summer AS isotopic biplot (Fig. 1), while the consumer standard ellipse areas (SEA) were, as expected, less influenced by these extreme values (Fig. 2).

The ES consumer community had a broader isotopic niche (TA and SEA) than the CS consumer community (Table $2 a$ ), as indicated by the Bayesian probabilities above 0.70 in winter and summer (Table 2b). The ES community also presented a more stable isotopic niche in terms of width and position than the CS and AS communities, as indicated by the similar niche widths, the Bayesian probability close to 0.5 and high SEA overlap between winter and summer (Fig. 2 and Table 2a). Finally, the isotopic niches of the two reef communities (ES and AS) overlapped more than each of them with the CS consumer community (Table 2b).

Between the winter and summer samplings, the CS isotopic niche shifted towards higher $\delta^{13} \mathrm{C}$ values compared to the AS and ES isotopic niches (Fig. 2) while the AS isotopic niche increased in width (Table 2a), presenting in summer a width similar to the ES isotopic niche (Table $2 b$ ), as indicated by the 
summer ES-AS Bayesian probability close to 0.5. Finally, all the consumer community isotopic niches were broader in summer than in winter (Bayesian probabilities $>0.76$, Table 2a).

\subsection{Isotopic compositions of the primary consumers and relative importance of benthic and pelagic} basal resources

Now, we consider only the primary consumer trophic level and investigate the relative importance of benthic and pelagic basal resources in fueling all primary consumers present in each sediment type and specific primary consumer species, using $\delta^{13} \mathrm{C}$ and $\delta^{15} \mathrm{~N}$ histograms (Fig. 3) and Bayesian mixing models (Fig. 4, Table 3 and S3). The CS primary consumers presented the highest mean $\delta^{13} \mathrm{C}$ values across the three sediment types (Fig. 3) indicating a higher contribution of ${ }^{13} \mathrm{C}$-enriched basal resources - like MPB (Fig. 1) - to their overall diet. Indeed, the global mixing model (Table 3) indicated that the CS primary consumers relied for over $80 \%$ on benthic basal resources (MPB contribution: $c a$. $88-90 \%$ ) whereas the ES and AS relied less on these resources (MPB+ULV contribution: ca. 48-76\%) and more on POM (contribution: $c a .23-52 \%$ ). More specifically, the dominant CS primary consumers relied on MPB in both winter and summer for more than $70 \%$ of their diet, except for L. levii and C. edule, which relied on a mixture of MPB and POM in winter and summer, respectively (Fig. 4 and Table S3). Benthic basal resources also contributed more to the ES primary consumers than they did to the AS primary consumers (Table 3), a difference visible through the higher mean $\delta^{13} \mathrm{C}$ of the ES primary consumers compared to the AS ones (Fig. 3) and mainly related to the stronger contribution of ULV to the diet of the ES primary consumers (Table 3).

Histograms of $\delta^{13} \mathrm{C}$ and $\delta^{15} \mathrm{~N}$ values of species sampled in the ES were overall flatter than the CS and AS histograms, a visual characteristic confirmed by the higher variability (standard deviation) in their carbon and nitrogen isotopic compositions than the CS and AS primary consumers (except the AS in summer) (Fig. 3). The $\delta^{13} \mathrm{C}$ ES histograms also displayed a secondary mode corresponding to high 
$\delta^{13} \mathrm{C}$ values ca. $-15 \%$ and $-14 \%$ in winter and summer, respectively (Fig. 3), indicating a high contribution of ${ }^{13} \mathrm{C}$-enriched basal resources such as MPB and/or ULV (Fig. 1) to the diet of certain primary consumers. Furthermore, the $\delta^{15} \mathrm{~N}$ histograms of the ES were slightly shifted towards higher values (Fig. 3), indicating a higher contribution of ${ }^{15} \mathrm{~N}$-enriched basal resources - such as ULV (Fig. 1)to the diet of certain primary consumers. Indeed, the grazing gastropods Steromphala umbilicalis (formerly known as Gibbula umbilicalis) and Littorina littorea, both present in the ES, relied exclusively on benthic basal resources (MPB and ULV, Table S3).

Across sediment types, the primary consumers displayed a lower average $\delta^{13} \mathrm{C}$ in summer than in winter, with a stronger shift visible for the AS and ES primary consumers than for the CS primary consumers (Fig. 3), indicating an overall higher contribution of ${ }^{13} \mathrm{C}$-depleted basal resources - such as POM (mostly phytoplankton, Fig. 1) - to their diets in summer than in winter. Indeed, the global mixing model indicated a strong increase in the importance of POM for the AS and ES primary consumers between winter (ca. 23-39\%) and summer (ca. 40-52\%) and only a very small shift for the CS primary consumers (Table 3).

More specifically, most of the dominant AS and ES primary consumers mainly relied ( $>70 \%$ contribution) on mixtures in winter: POM and MPB (AS: C. fornicata, R. philippinarum, and $V$. corrugata, ES: C. fornicata, M. cf. galloprovincialis, P. platycheles, and L. levii) or POM and ULV (AS: S. lamarckii, ES: M. gigas, Achelia spp., and M. palmata). Conversely, in summer, four primary consumers from the reef site (AS: R. philippinarum and S. lamarckii, ES: P. platycheles and Achelia spp.) relied on POM for over $70 \%$ of their diet and most of the other primary consumers relied on mixtures which contained POM: POM and MPB (AS: C. fornicata and L. levii, ES: M. cf. galloprovincialis, C. volutator and L. levii), or POM and ULV (AS: C. tentaculata and M. gigas, ES: M. gigas). Finally, respectively five and three of the dominant primary consumers of the reef site mainly relied on benthic basal resources in winter and summer; winter : C. tentaculata (AS) and G. vulgaris (ES) on MPB and 
ULV, L. levii (AS) on MPB, P. cultrifera (ES) and S. alveolata (ES) on ULV and summer: L. conchilega (AS) and M. fragilis (AS) on ULV, S. alveolata (ES) on MPB and ULV (Fig. 4 and Table S3). This list always included the engineer species.

\subsection{Trophic niches of dominant suspension-feeders in the engineered sediments}

Finally, we focus on the dominant suspension-feeders co-occurring in the engineered sediments and compare their respective realized trophic niches estimated with the Bayesian mixing models (Fig. 5). The engineer species $S$. alveolata showed a stable realized trophic niche (Fig. 5) with only a slight increase in the MPB mean dietary contribution between winter (28\%) and summer (35\%), compensated by a slight decrease in the ULV mean dietary contribution (Table S3). The realized trophic niches of $S$. alveolata and M. gigas, the two dominant species of the ES (Fig. 1 and Table S2), only slightly overlapped in winter and were very different from the realized trophic niches of the other co-occurring suspension-feeders in winter and summer (Fig. 5). Magallana gigas relied more on POM and less on MPB than S. alveolata, especially in summer and they both relied on ca. 40-50\% ULV (Fig. 5). Crepidula fornicata, $M$. cf. galloprovincialis, and P. platycheles displayed very similar realized trophic niches in winter and summer, relying on a mixture of POM and MPB with a contribution of ULV below 20\% (Fig. 5 and Table S3). Overall, all the dominant primary consumers except S. alveolata consumed more POM in summer than in winter (Fig. 5).

\section{DISCUSSION}

In 1994, Jones et al. defined ecosystem engineers as « organisms that directly or indirectly modulate the availability of resources to other species, by causing physical state changes in biotic or abiotic material ». Examples of such modulated resources included water, sediments, and nutrients. In this article, we go further than ecosystem engineering by looking into the fate of the modulated resources 
that are trophic in our case and discuss our results with regard to the gardening hypothesis. This hypothesis, developed for the lugworm Abarenicola pacifica, links the stimulation of a food source by a species - the lugworm stimulates microbes surrounding its burrow via its digestion and the production of feces - and the consumption of the stimulated or gardened resource by the same species (Hylleberg 1975). More recently, a similar mechanism has been highlighted in the case of oysters (Cognie \& Barillé 1999) and for the tubiculous amphipod Haploops nirae (Rigolet et al. 2014). We argue here that engineer species can also promote a habitat-wide form of gardening where an engineered habitat, in the present case a Sabellariid reef composed of the engineered and associated sediments, stimulates two basal trophic resources, which are then consumed by the engineer species and the associated organisms. We also stress the role played by this habitat-wide gardening in coupling two distinct communities, in our case the engineered and associated sediment communities (Jones et al. 2018), into a single reef food web and the different consequences this habitat-wide gardening has on the trophic structure and functioning of the engineered and associated sediment communities.

\subsection{The reef habitat stimulates benthic trophic resources and increases access to phytoplankton}

Large $S$. alveolata reefs, like the Sainte-Anne reef stimulate two basal trophic resources, green macroalgae from the genus Ulva (higher producer diversity), which relies on the physical structure of the engineered sediments to attach and grow (Dubois et al. 2006, Dubois \& Colombo 2014) and microphytobenthos biomass (higher producer biomass), which mainly develops on the associated sediments (Jones et al. 2018) through various physical and biological mechanisms mediated by the engineer species and the resulting biogenic structures. First, the engineered sediments are home to a diverse and abundant community of suspension-feeders (e.g. S. alveolata, M. gigas, Table 1) (Jones et al. 2018) that produce, through their filtration activity (Dubois et al. 2003, Cugier et al. 2010), large amounts of feces and pseudofeces (Haven \& Morales-Alamo 1966, Dubois et al. 2005). These 
biodeposits end up trapped between the $S$. alveolata tubes or sediment on the associated sediments (A. Jones unpubl. data) where they become a source of nutrients for benthic microalgae, once remineralized through the microbial loop (Hubas et al. 2006, van Broekhoven et al. 2015). Secondly, the physical structure of the engineered sediments acts as a wave-breaker, sheltering the associated sediments from the strong tidal currents and further promoting the development of dense microphytobenthos mats on these soft sediments (Jones 2017).

Structurally complex habitats like oyster reefs and polychaete tube mats often lead to the establishment of a skimming flow over them (Friedrichs et al. 2000, Passarelli et al. 2014). This flow promotes the local settlement of pelagic larvae (Commito et al. 2005, Donadi et al. 2014) and concentrates particulate organic matter just behind the biogenic structures (Colden et al. 2016). Consequently, this hydrodynamic phenomenon combined with the engineered sediments' erected position above the surrounding soft sediments probably result in a higher availability of phytoplankton for the primary consumers living in the engineered and associated sediments (González-Ortiz et al. 2014). Overall, through the physical structure of the engineered sediments and the abundant associated suspension-feeders, S. alveolata stimulates two basal trophic resources, microphytobenthos and green macroalgae, and increases the availability of phytoplankton for primary consumers.

\subsection{A habitat-wide gardening takes place inside the reef}

The global mixing model indicated that microphytobenthos and green macroalgae combined supported $76 \%$ and $60 \%$ of the engineered sediment food web, in winter and summer respectively, revealing the importance of the two gardened resources in the trophic functioning of this community (Table 3). A few primary consumers (i.e. Sabellaria alveolata, Littorina littorea, Steromphala umbilicalis, Golfingia vulgaris) from different trophic guilds strongly drove this trend while the rest of the primary consumers relied for no more than $60 \%$ on green macroalgae and microphytobenthos, 
globally supporting the gardening hypothesis to a more or less large extend depending on the species (Fig. 4, Table S3). Littorina littorea and S. umbilicalis, two common grazing gastropods present at low densities across the engineered sediments and the more abundant deposit-feeding sipunculid G. vulgaris (Dubois et al. 2002, Jones et al. 2018), relied for over $90 \%$ on microphytobenthos and/or green macroalgae with shifts between the two contrasted sampling periods (winter and summer). Furthermore, the suspension-feeding engineer species $S$. alveolata displayed a very similar realized trophic niche in winter and summer based for $75 \%$ on the gardened trophic resources, green macroalgae (40-48\%) and microphytobenthos (28-35\%), indicating a positive and stable trophic feedback between the engineer species and the engineered habitat.

Globally, the gardened resources fueled less the associated sediment food web with a $61 \%$ and $48 \%$ contribution in winter and summer respectively (Table 3 ). Nonetheless, these resources contributed for over $70 \%$ to the winter diet of a few suspension-feeders like the cockle Cerastoderma edule and the solid surf clam Spisula solida and of the deposit-feeding polychaete Cirriformia tentaculata (Table S3). The promotion of a trophic resource by one species, here $S$. alveolata via the habitat it creates, and its consumption by associated species, expands the ecosystem engineering definition, which historically only focused on the modulation of the availability of resources to other species (Jones et al. 1994). This process has been observed in the case of $H$. nirae tube mats, where the diatoms growing on the tubes contribute up to $50 \%$ of the diet of the dominant species associated with this engineered habitat, such as the bivalve Polititapes virgineus (Rigolet et al. 2014). Overall, our results support the hypothesis of a habitat-wide gardening at the scale of the engineered and associated sediments with nonetheless, a high inter-specific variability in the reliance of each primary consumer on the gardened resources.

Finally, the similar realized trophic niche of the engineer species in winter and summer seems to indicate that $S$. alveolata creates optimal and very stable trophic conditions for itself (Fig. 5). Conversely, the other primary consumers present in the engineered and associated sediments changed 
diets between winter and summer, maybe indicating the engineered habitat does not provide them with such optimal conditions (Fig. 4 and 5, Table S3). These primary consumers likely shift their diet according to the spatio-temporal abundance and availability of basal resources, for example by consuming more phytoplankton and/or green macroalgae in summer when these resources are more abundant (Dubois et al. 2006, Marín Leal et al. 2008, Cugier et al. 2010).

4.3. Phytoplankton, a key trophic resource for the reef primary consumers, locally couples the pelagic and benthic compartments

Our second hypothesis stated that the increased microphytobenthos biomass in the associated sediments and the presence of green macroalgae growing on the engineered sediments would lead to a higher trophic contribution of these locally stimulated benthic resources to the engineered and associated sediment communities than to the control sediment community. The global mixing model revealed the opposite trend, with an average $21-34 \%$ lower contribution of these benthic basal resources to the diet of the engineered and associated sediment primary consumers (MPB + ULV) than to the diet of the control sediment primary consumers (MPB) (Table 3). Microphytobenthos fueled around $90 \%$ of the winter and summer basal carbon flows taking place inside the control sediments, confirming the importance of benthic primary producers in sustaining temperate intertidal soft-sediment food webs, as previously demonstrated in similar systems like Wadden Sea (Middelburg et al. 2000, Christianen et al. 2017).

The engineered habitat (ES and AS) also concentrates phytoplankton (part 4.1), which is then consumed by the engineered and associated sediment primary consumers, as indicated by the diverse suspension- and deposit-feeders present in both sediment types and the mixing model results (Fig. 1 and 4, Table 1, 3 and S3). The two sediment types composing the engineered habitat are home to a high diversity of suspension-feeders (e.g. S. alveolata, M. gigas, V. corrugata, C. fornicata, R. philippinarum) 
that can directly consume phytoplankton and to surface deposit-feeders that can consume phytoplankton once deposited on the engineered (e.g. C. volutator, L. levii) or on the associated sediments (Mediomastus fragilis, Cirriformia tentaculata). Furthermore, phytoplankton represented over $30 \%$ of the assimilated diet of at least half of the dominant engineered and associated sediment primary consumers, fueled 23$40 \%$ of the basal carbon flows taking place in the engineered sediments, and even more in the associated sediments (39-52\%), with a higher contribution in summer than in winter across both sediment types. Consequently, phytoplankton appears as a key trophic resource for the two reef communities, especially in summer when it is more abundant (Marín Leal et al. 2008, Cugier et al. 2010). Our results also indicate that through its physical properties that promote phytoplankton sedimentation and its rich and diverse macrofauna which consumes it, the habitat engineered by $S$. alveolata and composed of the engineered and associated sediments, acts as a local hotspot for benthic-pelagic coupling (Griffiths et al. 2017) (Griffiths et al. 2017), similarly to bivalve reefs (Dame et al. 2000).

4.4. Trophic connections link the engineered and associated sediment communities into a single reeffood web

Communities from the engineered and associated sediments have been so far studied independently because of their different structural nature and distinct species assemblages (Jones et al. 2018) but many mechanisms link these two communities into a single reef food web, starting with trophic connections associated with the habitat-wide gardening. Trophic connections between adjacent habitats can be established through the movements of nutrients (e.g. carbon, nitrogen, and phosphorus), detritus (e.g. biodeposits and phytodetritus), prey (e.g. primary producers) and consumers (Polis et al. 1997). For example, in the case of $H$. nirae beds and the adjacent Amphiura filiformis muddy habitat, a trophic connection exists through the exportation of benthic microalgae growing on Haploops tubes (Rigolet et al. 2014). 
In our case, the engineered and associated sediments are probably primarily connected throughout the year by movements of basal resources (see part 4.1), biodeposits (see part 4.1) and consumers (Fig. 4, Table 1 and S3). Indeed, deposit-feeders exclusively present in the associated sediments (e.g. Cirriformia tentaculata) assimilate green macroalgae indicating macroalgae fragments move from the engineered to the associated sediments. A diversity of primary consumers exclusively present in the engineered sediments (Corophium volutator, Porcellana platycheles) and the engineer species itself assimilate microphytobenthos meaning there is a movement of microphytobenthos from the associated to the engineered sediments via resuspension (Ubertini et al. 2012), as found for cultivated oysters and associated suspension-feeders (Dubois et al. 2007). Furthermore, a number of vagile primary (e.g. Lekanesphaera levii) and secondary consumers (e.g. Tritia reticulata, Carcinus maenas, Crangon crangon, Pomatoschistus sp.) present in both sediment types presented very similar isotopic compositions, suggesting they move and forage between the engineered and associated sediments (Table S2). These trophic connections were established indirectly using naturally present carbon and nitrogen stable isotopes but in situ isotope labeling of the microphytobenthos present in the associated sediments and of the green macroalgae present on the engineered sediments would provide an interesting complementary line of evidence (Middelburg et al. 2000, Majdi et al. 2018).

Overall, the engineered and associated sediment communities, despite their different sedimentary nature and species composition, appear connected through energy flows mostly linked to the basal node modulation induced by $S$. alveolata. Accordingly, the habitat engineered by S. alveolata is composed of two sediment type communities but, most likely, is organized into a single reef food web, lending more weight to the hypothesis that the $S$. alveolata reefs present on soft substrates are a unique ecological entity composed of the biogenic structures and the adjacent soft sediments (Jones et al. 2018).

\subsection{Global effects of the habitat-wide gardening on the reef food web structure and functioning}


The ecosystem engineer S. alveolata builds a habitat composed of two sediment types, the engineered and associated sediments, different in their physical nature, abiotic characteristics and species assemblages, which actually seem to be coupled into a single reef habitat and food web by movements of locally stimulated basal trophic resources (microphytobenthos and green macroalgae), biodeposits resulting from the high filtration activity of the engineered sediment suspension-feeders and mobile consumers. Furthermore, the gardening hypothesis seems validated at the reef habitat scale (ES and AS), as indicated by the stimulation of two basal trophic resources, microphytobenthos and green macroalgae, which then partly fuel the reef food web via their consumption by diverse primary consumers and especially the suspension-feeding engineer species and grazers. This habitat-wide gardening also has consequences on the food web organization and functioning of the engineered and associated sediment communities with notably a widening of their community isotopic niches and a limitation of the interspecific trophic competition between the engineer species and abundant co-occurring suspensionfeeders.

First, the presence of $S$. alveolata increased the engineered sediment consumer community isotopic niche width in winter and summer (Fig. 2, Table 2), agreeing with our first hypothesis and a theoretical framework that links ecosystem engineering and food webs via node and link modulation (Sanders et al. 2014). Indeed, basal node modulation (i.e. stimulation of microphytobenthos and green macroalgae) diversifies available trophic niches, which can lead to the establishment of a more diverse consumer community, the development of new energy pathways and to an overall increase in the width of the consumer community isotopic niche (Layman et al. 2007). Trophic (i.e. gardened basal resources) and spatial niche diversification (i.e. habitat provisioning) promoted by $S$. alveolata probably led to the observed increase in the engineered sediment species richness (Jones et al. 2018, Table 1), a result partly linked to the establishment of gardened resource trophic specialists, and finally led to the overall wider isotopic niche. Overall, habitat modifiers like cordgrass and seagrass, increase species richness across 
trophic levels and increase link density through their non-trophic facilitative role rather than through their trophic role (van der Zee et al. 2016), as it seems to be the case for S. alveolata.

Interestingly, empirical studies on habitats engineered by the amphipod Haploops nirae (Rigolet et al. 2014), the polychaete Lanice conchilega (De Smet et al. 2015) and the marine plant Zostera marina (Jankowska et al. 2018) did not detect strong effects of these species on the food web structure of softbottom communities, despite drastic changes in environmental conditions, consumer richness and species assemblages. These contrasting findings could result from the level of structural and spatio-temporal stability of each habitat (Jones et al. 1994, 1997). Indeed, the structures engineered by S. alveolata (engineered sediments) are solid and very resistant (Le Cam et al. 2011), much closer structurally to coral reefs than to habitats built by H. nirae, L. conchilega, or Z. marina (Goldberg 2013). The Sainte-Anne reef has also been recorded at the same site and with similar dimensions for decades (Caline et al. 1992, Dubois et al. 2002), whereas seagrass meadows undergo substantial seasonal changes with often clear declines in shoot density and aboveground biomass during winter (Jankowska et al. 2018). Similarly, intertidal L. conchilega beds are characterized by an inter-annual variability in their surface and in the engineer density (Callaway et al. 2010).

We also observed a similar width of the engineered sediment isotopic niche between our two contrasted sampling times, as we observed for the engineer species, and a similar biomass distribution, indicating $S$. alveolata not only creates stable trophic conditions for itself, but also for the entire consumer community associated with the engineered sediments (Fig. 1 and 2, Table 1). Complex food webs can emerge from the establishment of engineer species via habitat provisioning, limited physical stress, and mediated energy and nutrient flow (van der Zee et al. 2016). In our case, the emergence of a complex and relatively stable engineered sediment food web was probably driven by the spatio-temporal stability of the engineer density and of the resulting physical structure (e.g. surface, height), known to directly and indirectly affect the stability of assembling food webs (Neutel et al. 2007). 
Furthermore, the associated sediment community presented the highest isotopic niche width difference between winter and summer and the strongest temporal variability in the dominant trophic groups, pointing to a less stable trophic structure of this community compared with the engineered and control sediment communities (Fig. 1 and 2, Table 1 and 2). The turbulent hydrodynamic environment created by the engineered sediments (Colden et al. 2016) and the recurrent disturbance by local fishermen of the associated sediments (Watson et al. 2017) result in a high spatio-temporal variability in the abiotic (e.g. principal grain size mode, mud content) and biotic (species assemblage) characteristics of these sediments (Desroy et al. 2011, Jones et al. 2018). Nonetheless, in summer, the associated and engineered sediment isotopic niches had similar widths, a result partly agreeing with our first hypothesis. This stronger trophic connection between the two reef communities observed in summer is probably linked to the higher abundance of gardened basal resources in summer (Dubois et al. 2006, Marín Leal et al. 2008) and to the recruitment promoting role of the engineered sediments (Jones et al. 2018) that lead to the establishment in the associated sediments of a community more characterized by suspension and depositfeeders - two trophic groups that benefit from the gardened basal resources - in summer than in winter. The isotopic niche overlap between the engineered and associated sediment communities was also higher than between each community and the control sediment community in winter and summer (Fig. 2, Table 2). Consequently, the two reef communities are more similar overall in their trophic structure than the $L$. balthica community characterizing the control sediments (Bonnot-Courtois et al. 2009) and in summer, the "trophic effect" of $S$. alveolata (isotopic niche widening) seems to extend beyond the physical border of the engineered sediments and towards the associated sediments.

Sabellariid reefs also provide hard substrata for many epibionts, including the Japanese oyster $M$. gigas which sometimes dominates the biogenic structures (Dubois et al. 2006, Jones et al. 2018, Table 1) and a diversity of other suspension-feeders like mussels (M. cf. galloprovincialis), slipper limpets (C. fornicata) and porcellanid crabs (P. platycheles), which sometimes reach densities over 2500 ind. $\mathrm{m}^{-2}$ and 
account for over $10 \%$ of the community biomass (Jones et al. 2018). As suspension-feeders, these cooccurring species may share similar diets. Using stable isotopes, we did not detect an overlap between the realized trophic niche of $S$. alveolata and the co-occurring suspension-feeders, expect a small one with M. gigas in winter (Fig. 5) when M. gigas's main food sources (i.e. phytoplankton and green macroalgae) are more limiting (Dubois et al. 2006, Marín Leal et al. 2008). Overall, there appears to be no trophic competition between the engineer and the most abundant suspension-feeders, probably as a result of inter-specific trophic partitioning directly linked to the strong reliance of the engineer species (ca. 75\%) on the gardened resources (i.e. microphytobenthos and green macroalgae). Similarly, the development of benthic diatoms on the tubes of the ecosystem engineer $H$. nirae limits inter-specific food competition between the engineer and the dominant primary consumers (Rigolet et al. 2014), a mechanism also highlighted in other S. alveolata reefs (Dubois \& Colombo 2014) and inside oyster farms (Dubois et al. 2007).

Most co-occurring suspension-feeders use different feeding mechanisms to capture, transport and sort particles from the water column, resulting in different selection capacities and retention efficiencies (Dubois et al. 2005), hence favouring inter-specific trophic partitioning. The stimulation of basal trophic resources by an engineer species which then consumes them - a.k.a. gardening - also limits inter-specific trophic competition for the engineer species (Dubois et al. 2007, Rigolet et al. 2014, Dubois \& Colombo 2014), as demonstrated here for S. alveolata. Overall, S. alveolata appears to engineer a habitat where its chances of survival are maximized mainly through basal trophic resource gardening. Nonetheless, S. alveolata and M. gigas are at high risks of competing for space (Dubois et al. 2006) and for food in winter, especially if microphytobenthos and phytoplankton become less abundant. Consequently, the non-native Japanese oysters could jeopardize the survival of $S$. alveolata reefs in the long run, a potentially negative role that should be further investigated to help protect these habitats, as encouraged by the European Union's Habitats Directive 92/43/EEC (habitat type 1170 'Reef'). 


\section{Conclusion}

The honeycomb-worm Sabellaria alveolata can build extensive and long-lived reefs composed of the engineered structures and adjacent soft sediments in intertidal zones. Our analysis of the food web structure and functioning of the consumer communities associated with these two sediment types (associated and engineered sediments) and their comparison with a control soft sediment provides an integrated view on the coupling of non-trophic (ecosystem engineering) and trophic (basal resource consumption) interactions by a structural ecosystem engineer (Berke 2010). First, a habitat-wide gardening takes place within $S$. alveolata reefs, characterized by the stimulation of basal trophic resources, via abiotic (physical structure of the engineered sediments) and biotic (suspension-feeding) mechanisms, which are then consumed by diverse primary consumers including the engineer species. These reefs also promote phytoplankton sedimentation, a key trophic resource for a diversity of suspension and deposit-feeders especially in summer, hence locally increasing benthic-pelagic coupling. Secondly, basal trophic resource stimulation and the associated consumers' feeding activity and movements, couple the engineered and associated sediment communities into a single reef food web. These stimulated basal resources also diversify the trophic pathways inside the reef, promote trophic resource partitioning and limit trophic competition between the engineer species and associated suspension-feeders. In the end, S. alveolata engineers a temporally stable and probably highly resilient coastal habitat, which strongly controls energy flows in coastal environments.

We believe the results we found at the scale of the Sainte-Anne reef can be generalized to any engineered habitat in which trophic basal resources are stimulated, a mechanism probably more intense in extensive and cohesive engineered habitats (i.e. surface area $>1000 \mathrm{~m}^{2}$ ) that persist over time (i.e. several years) like coral, polychaete and bivalve reefs (Engel et al. 2017). Indeed, structural engineers like tube-building invertebrates and bivalves are expected to "operate through similar processes and have 
similar types of effects" (Berke 2010). Finally, expanding our study over multiple years and performing similar studies on extensive mussel and oyster reefs would help to better evaluate the temporal stability of the Sabellaria alveolata reef food web, to investigate how general our findings are and to eventually determine more precisely engineered habitat characteristics associated to temporally stable and resilient food webs. Protecting the habitats with these characteristics could help buffer the effects of climate change in coastal ecosystems as suggested by Bulleri et al. (2018).

\section{Acknowledgements}

This project was funded by an EC2CO DRIL (CNRS AO2016-993962) grant. A. G. J. was supported by the "Laboratoire d'Excellence" LabexMER (ANR-10-LABX-19) and co-funded by a grant from the French government under the program "Investissements d'Avenir" and by a Région Bretagne/Ifremer $\mathrm{PhD}$ grant. This work is partially based on the doctoral thesis by A. G. J. Our funding source had no involvement in this study. We wish to thank all the people who helped us on the field (Ludovic Goyot, Ségolène Jambut, François Gaudin, Patrick Le Mao, Anthony Sturbois, Daniel Gerla, Julien Chevé, Claire Rollet, Renée Taraud, Priscilla Decottignies, Pierre Gernez, Laurent Barillé, and Bernard "Pompon” Delaunay) and in the lab (Angelica Navarro, Sarah Gouge, and Maïwenn Lescop). A special thanks to Kimberley Sparks from the Cornell Stable Isotope lab and to Oanez Lebeau from the IUEM Stable Isotope lab for the swift stable isotope analysis. A final thanks to Helen McCombie Boudry from the translation office of the University of Western Brittany for the editing this manuscript.

\section{References}

Androuin T, Dubois SF, Decottignies P, Pelleter E, Carlier A (2019) The dark side of soft tissues: Unexpected inorganic carbonate in the invasive slipper limpet Crepidula fornicata and its implications for stable isotope interpretations. Rapid Communications in Mass Spectrometry 33:107-115. 
Ayata S-D, Ellien C, Dumas F, Dubois S, Thiebaut E (2009) Modelling larval dispersal and settlement of the reef-building polychaete Sabellaria alveolata: Role of hydroclimatic processes on the sustainability of biogenic reefs. Continental Shelf Research 29:1605-1623.

Berke SK (2010) Functional groups of ecosystem engineers: a proposed classification with comments on current issues. Integr Comp Biol 50:147-157.

Blanchard G, Chretiennot-Dinet MJ, Dinet A, Robert J-M (1988) Méthode simplifiée pour l'extraction du microphytobenthos des sédiments marins par le gel de silice Ludox. Comptes rendus de l'Académie des sciences Série 3, Sciences de la vie 307:569-576.

Bonnot-Courtois C, Caline B, L'Homer A, Le Vot M (2002) The Bay of Mont-Saint-Michel and the Rance Estuary, recent development and evolution of depositional environments. CNRS, EPHE, Pau.

Bonnot-Courtois C, Maze JP, Le Vot M, Augris C, Ehrhold A, Simplet L, Blanchard M (2009) Carte morpho-sédimentaire de la baie du Mont Saint-Michel (Ille-et-Vilaine et Manche) échelle 1/25 000, Quae. Ifremer.

Brind'Amour A, Dubois SF (2013) Isotopic diversity indices: how sensitive to food web structure? PLOS ONE 8:e84198.

van Broekhoven W, Jansen H, Verdegem M, Struyf E, Troost K, Lindeboom H, Smaal A (2015) Nutrient regeneration from feces and pseudofeces of mussel Mytilus edulis spat. Marine Ecology Progress Series 534:107-120.

Bruschetti M (2019) Role of reef-building, ecosystem engineering polychaetes in shallow water ecosystems. Diversity 11:168.

Buffet J-P, Corre E, Duvernois-Berthet E, Fournier J, Lopez PJ (2018) Adhesive gland transcriptomics uncovers a diversity of genes involved in glue formation in marine tube-building polychaetes. Acta Biomater 72:316-328.

Bulleri F, Eriksson BK, Queirós A, Airoldi L, Arenas F, Arvanitidis C, Bouma TJ, Crowe TP, Davoult D, Guizien K, Iveša L, Jenkins SR, Michalet R, Olabarria C, Procaccini G, Serrão EA, Wahl M, Benedetti-Cecchi L (2018) Harnessing positive species interactions as a tool against climate-driven loss of coastal biodiversity. PLOS Biology 16:e2006852.

Caillaud M, Petton S, Dumas F, Rochette S, Mickael V (2016) Rejeu hydrodynamique à $500 \mathrm{~m}$ de résolution avec le modèle MARS3D-AGRIF - 8 zooms. https://sextant.ifremer.fr/record/c1371cc1f116-4c4f-aaff-bc2ef71a1729/ (accessed January 8, 2017)

Caline B, Gruet Y, Legendre C, Le Rhun J, L'Homer A, Mathieu R, Zbinden R (1992) The Sabellariid reefs in the bay of Mont Saint-Michel, France: Ecology, geomorphology, sedimentology, and geologic implications, Florida Oceanographic Society. Florida.

Callaway R, Desroy N, Dubois SF, Fournier J, Frost M, Godet L, Hendrick VJ, Rabaut M (2010) Ephemeral bio-engineers or reef-building polychaetes: how stable are aggregations of the tube worm Lanice conchilega (Pallas, 1766)? Integr Comp Biol 50:237-250. 
Christianen MJA, Middelburg JJ, Holthuijsen SJ, Jouta J, Compton TJ, van der Heide T, Piersma T, Sinninghe Damsté JS, van der Veer HW, Schouten S, Olff H (2017) Benthic primary producers are key to sustain the Wadden Sea food web: stable carbon isotope analysis at landscape scale. Ecology 98:1498-1512.

Cognie B, Barillé L (1999) Does bivalve mucus favour the growth of their main food source, microalgae? Oceanologica Acta 22:441-450.

Colden AM, Fall KA, Cartwright GM, Friedrichs CT (2016) Sediment suspension and deposition across restored oyster reefs of varying orientation to flow: implications for restoration. Estuaries and Coasts 39:1435-1448.

Commito JA, Celano EA, Celico HJ, Como S, Johnson CP (2005) Mussels matter: postlarval dispersal dynamics altered by a spatially complex ecosystem engineer. Journal of Experimental Marine Biology and Ecology 316:133-147.

Cugier P, Struski C, Blanchard M, Mazurié J, Pouvreau S, Olivier F, Trigui JR, Thiébaut E (2010) Assessing the role of benthic filter feeders on phytoplankton production in a shellfish farming site: Mont Saint Michel Bay, France. Journal of Marine Systems 82:21-34.

Dame RF, Koepfler E, Gregory L (2000) Benthic-pelagic coupling in marsh-estuarine ecosystems. In: Concepts and Controversies in Tidal Marsh Ecology. Weinstein MP, Kreeger DA (eds) Springer Netherlands, Dordrecht, p 369-390

De Smet B, Fournier J, Troch MD, Vincx M, Vanaverbeke J (2015) Integrating ecosystem engineering and food web ecology: testing the effect of biogenic reefs on the food web of a soft-bottom intertidal area. PLOS ONE 10:e0140857.

Desroy N, Dubois SF, Fournier J, Ricquiers L, Le Mao P, Guerin L, Gerla D, Rougerie M, Legendre A (2011) The conservation status of Sabellaria alveolata (L.) (Polychaeta: Sabellariidae) reefs in the Bay of Mont-Saint-Michel. Aquatic Conservation: Marine and Freshwater Ecosystems 21:462471.

Donadi S, van der Zee EM, van der Heide T, Weerman EJ, Piersma T, van de Koppel J, Olff H, Bartelds M, van Gerwen I, Eriksson BK (2014) The bivalve loop: Intra-specific facilitation in burrowing cockles through habitat modification. Journal of Experimental Marine Biology and Ecology 461:44-52.

Dubois S, Barillé L, Cognie B, Beninger PG (2005) Particle capture and processing mechanisms in Sabellaria alveolata (Polychaeta: Sabellariidae). Marine Ecology Progress Series 301:159-171.

Dubois S, Barillé L, Retière C (2003) Efficiency of particle retention and clearance rate in the polychaete Sabellaria alveolata L. Comptes Rendus Biologies 326:413-421.

Dubois S, Commito JA, Olivier F, Retière C (2006) Effects of epibionts on Sabellaria alveolata (L.) biogenic reefs and their associated fauna in the Bay of Mont Saint-Michel. Estuarine, Coastal and Shelf Science 68:635-646. 
Dubois S, Orvain F, MarinLal JC, Ropert M, Lefebvre S (2007) Small-scale spatial variability of food partitioning between cultivated oysters and associated suspension-feeding species, as revealed by stable isotopes. Mar Ecol Prog Ser 336:151-160.

Dubois S, Retière C, Olivier F (2002) Biodiversity associated with Sabellaria alveolata (Polychaeta: Sabellariidae) reefs: effects of human disturbances. Journal of the Marine Biological Association of the United Kingdom 82:817-826.

Dubois SF, Colombo F (2014) How picky can you be? Temporal variations in trophic niches of co-occurring suspension-feeding species. Food Webs 1:1-9.

Echappé C, Gernez P, Méléder V, Jesus B, Cognie B, Decottignies P, Sabbe K, Barillé L (2017) Satellite remote sensing reveals a positive impact of living oyster reefs on microalgal biofilm development. Biogeosciences Discuss 2017:1-30.

Engel FG, Alegria J, Andriana R, Donadi S, Gusmao JB, van Leeuwe MA, Matthiessen B, Eriksson BK (2017) Mussel beds are biological power stations on intertidal flats. Estuarine, Coastal and Shelf Science 191:21-27.

Fauchald K, Jumars PA (1979) The diet of worms: a study of polychaete feeding guilds. Aberdeen University Press.

Friedrichs M, Graf G, Springer B (2000) Skimming flow induced over a simulated polychaete tube lawn at low population densities. Marine Ecology Progress Series 192:219-228.

Goldberg WM (2013) The biology of reefs and reef organisms. The University of Chicago Press, Chicago and London.

González-Ortiz V, Egea LG, Jiménez-Ramos R, Moreno-Marín F, Pérez-Lloréns JL, Bouma TJ, Brun FG (2014) Interactions between seagrass complexity, hydrodynamic flow and biomixing alter food availability for associated filter-feeding organisms. PLOS ONE 9:e104949.

Griffiths JR, Kadin M, Nascimento FJA, Tamelander T, Törnroos A, Bonaglia S, Bonsdorff E, Brüchert V, Gårdmark A, Järnström M, Kotta J, Lindegren M, Nordström MC, Norkko A, Olsson J, Weigel B, Žydelis R, Blenckner T, Niiranen S, Winder M (2017) The importance of benthic-pelagic coupling for marine ecosystem functioning in a changing world. Global Change Biology 23:2179-2196.

Gruet Y (1972) Aspects morphologiques et dynamiques de constructions de l'Annelide polychete Sabellaria alveolata (Linne). Revue des Travaux de 1'Institut des Pêches Maritimes 36:131161.

Guerra-García JM, Tierno de Figueroa JM, Navarro-Barranco C, Ros M, Sánchez-Moyano JE, Moreira J (2014) Dietary analysis of the marine Amphipoda (Crustacea: Peracarida) from the Iberian Peninsula. Journal of Sea Research 85:508-517.

Gutiérrez JL, Jones CG, Byers JE, Arkema KK, Berkenbusch K, Commito A, Duarte CM, Hacker SD, Lambrinos JG, Hendriks IE, Hogarth PJ, Palomo MG, Wild C (2012) Physical ecosystem 
engineers and the functioning of estuaries and coasts. Treatise on Estuarine and Coastal Science 7:5381.

Haven DS, Morales-Alamo R (1966) Aspects of biodeposition by oysters and other invertebrate filter feeders. Limnology and Oceanography 11:487-498.

Holt TJ, Rees EI, Hawkins SJ, Seed R (1998) Biogenic reefs. An overview of dynamic and sensitivity characteristics for conservation management of marine SACs. Scottish Association for Marine Science, UK Marine SACs Project.

Hondula KL, Pace ML (2014) Macroalgal support of cultured hard clams in a low nitrogen coastal lagoon. Marine Ecology Progress Series 498:187-201.

Hubas C, Lamy D, Artigas LF, Davoult D (2006) Seasonal variability of intertidal bacterial metabolism and growth efficiency in an exposed sandy beach during low tide. Marine Biology 151:4152.

Hylleberg J (1975) Selective feeding by Abarenicola pacifica with notes on Abarenicola vagabunda and a concept of gardening in lugworms. Ophelia 14:113-137.

Jackson AL, Inger R, Parnell AC, Bearhop S (2011) Comparing isotopic niche widths among and within communities: SIBER - Stable Isotope Bayesian Ellipses in R. Journal of Animal Ecology 80:595-602.

Jankowska E, De Troch M, Michel LN, Lepoint G, Włodarska-Kowalczuk M (2018) Modification of benthic food web structure by recovering seagrass meadows, as revealed by trophic markers and mixing models. Ecological Indicators 90:28-37.

Jones A (2017) Effect of an engineer species on the diversity and functioning of benthic communities : the Sabellaria alveolata reef habitat. Theses, Université de Bretagne occidentale - Brest

Jones AG, Dubois SF, Desroy N, Fournier J (2018) Interplay between abiotic factors and species assemblages mediated by the ecosystem engineer Sabellaria alveolata (Annelida: Polychaeta). Estuarine, Coastal and Shelf Science 200:1-18.

Jones CG, Gutiérrez JL, Byers JE, Crooks JA, Lambrinos JG, Talley TS (2010) A framework for understanding physical ecosystem engineering by organisms. Oikos 119:1862-1869.

386.

Jones CG, Lawton JH, Shachak M (1994) Organisms as ecosystem engineers. Oikos 69:373-

Jones CG, Lawton JH, Shachak M (1997) Positive and negative effects of organisms as physical ecosystem engineers. Ecology 78:1946-1957.

Jumars PA, Dorgan KM, Lindsay SM (2015) Diet of worms emended: an update of polychaete feeding guilds. Annual Review of Marine Science 7:497-520. 
Layman CA, Arrington DA, Montaña CG, Post DM (2007) Can stable isotope ratios provide for community-wide measures of trophic structure? Ecology 88:42-48.

Le Cam J-B, Fournier J, Etienne S, Couden J (2011) The strength of biogenic sand reefs: Viscoelastic behaviour of cement secreted by the tube building polychaete Sabellaria alveolata, Linnaeus, 1767. Estuarine, Coastal and Shelf Science 91:333-339.

Lefebvre S, Dubois SF (2016) The stony road to understand isotopic enrichment and turnover rates : insight into the metabolic part. Vie et Milieu 66:305-314.

Lorrain A, Savoye N, Chauvaud L, Paulet Y-M, Naulet N (2003) Decarbonation and preservation method for the analysis of organic $\mathrm{C}$ and $\mathrm{N}$ contents and stable isotope ratios of lowcarbonated suspended particulate material. Analytica Chimica Acta 491:125-133.

Majdi N, Hette-Tronquart N, Auclair E, Bec A, Chouvelon T, Cognie B, Danger M, Decottignies P, Dessier A, Desvilettes C, Dubois S, Dupuy C, Fritsch C, Gaucherel C, Hedde M, Jabot F, Lefebvre S, Marzloff MP, Pey B, Peyrard N, Powolny T, Sabbadin R, Thébault E, Perga M-E (2018) There's no harm in having too much: A comprehensive toolbox of methods in trophic ecology. Food Webs 17:e00100.

Marín Leal JC, Dubois S, Orvain F, Galois R, Blin J-L, Ropert M, Bataillé M-P, Ourry A, Lefebvre S (2008) Stable isotopes $(\delta 13 \mathrm{C}, \delta 15 \mathrm{~N})$ and modelling as tools to estimate the trophic ecology of cultivated oysters in two contrasting environments. Mar Biol 153:673-688.

McCutchan JH, Lewis WM, Kendall C, McGrath CC (2003) Variation in trophic shift for stable isotope ratios of carbon, nitrogen, and sulfur. Oikos 102:378-390.

McGarigal K, Cushman SA, Ene E (2012) FRAGSTATS v4: Spatial pattern analysis program for categorical and continuous maps. University of Massachusetts.

Middelburg JJ, Barranguet C, Boschker HTS, Herman PMJ, Moens T, Heip CHR (2000) The fate of intertidal microphytobenthos carbon: An in situ 13C-labeling study. Limnology and Oceanography 45:1224-1234.

Muir AP, Nunes FLD, Dubois SF, Pernet F (2016) Lipid remodelling in the reef-building honeycomb worm, Sabellaria alveolata, reflects acclimation and local adaptation to temperature. Scientific Reports 6.

Navarro-Barranco C, Tierno-de-Figueroa JM, Guerra-García JM, Sánchez-Tocino L, GarcíaGómez JC (2013) Feeding habits of amphipods (Crustacea: Malacostraca) from shallow soft bottom communities: comparison between marine caves and open habitats. Journal of Sea Research 78:1-7.

Neutel A-M, Heesterbeek JAP, van de Koppel J, Hoenderboom G, Vos A, Kaldeway C, Berendse F, de Ruiter PC (2007) Reconciling complexity with stability in naturally assembling food webs. Nature 449:599-602.

Noernberg MA, Fournier J, Dubois S, Populus J (2010) Using airborne laser altimetry to estimate Sabellaria alveolata (Polychaeta: Sabellariidae) reefs volume in tidal flat environments. Estuarine, Coastal and Shelf Science 90:93-102. 
Parnell AC (2016) Simmr: A Stable Isotope Mixing Model.

Parnell AC, Jackson JBC (2013) Siar: Stable Isotope Analysis in R.

Parnell AC, Phillips DL, Bearhop S, Semmens BX, Ward EJ, Moore JW, Jackson AL, Grey J, Kelly DJ, Inger R (2013) Bayesian stable isotope mixing models. Environmetrics 24:387-399.

Passarelli C, Olivier F, Paterson DM, Meziane T, Hubas C (2014) Organisms as cooperative ecosystem engineers in intertidal flats. Journal of Sea Research 92:92-101.

Polis GA, Wendy B. Anderson1, and, Holt RD (1997) Toward an integration of landscape and food web ecology: the dynamics of spatially subsidized food webs. Annual Review of Ecology and Systematics 28:289-316.

R Core Team (2018) R: A language and environment for statistical computing. R Foundation for Statistical Computing, Vienna, Austria.

Riera P (2007) Trophic subsidies of Crassostrea gigas, Mytilus edulis and Crepidula fornicata in the Bay of Mont Saint Michel (France): A $\delta 13 \mathrm{C}$ and $\delta 15 \mathrm{~N}$ investigation. Estuarine, Coastal and Shelf Science 72:33-41.

Rigolet C, Thiébaut E, Dubois SF (2014) Food web structures of subtidal benthic muddy habitats: evidence of microphytobenthos contribution supported by an engineer species. Marine Ecology Progress Series 500:25-41.

Romero GQ, Gonçalves-Souza T, Vieira C, Koricheva J (2015) Ecosystem engineering effects on species diversity across ecosystems: a meta-analysis. Biological Reviews 90:877-890.

Salomon J-C, Breton M (1991) Courants résiduels de marée dans la Manche. Oceanologica Acta Sp. $11: 47-53$.

Sanders D, Jones CG, Thébault E, Bouma TJ, van der Heide T, van Belzen J, Barot S (2014) Integrating ecosystem engineering and food webs. Oikos 123:513-524.

Secula C (2011) Acteurs et gestion du littoral. Une anthropologie de la baie du Mont-SaintMichel. PhD thesis, Museum national d'histoire naturelle - MNHN PARIS

Stallins JA (2006) Geomorphology and ecology: Unifying themes for complex systems in biogeomorphology. Geomorphology 77:207-216.

Ubertini M, Lefebvre S, Gangnery A, Grangeré K, Gendre RL, Orvain F (2012) Spatial variability of benthic-pelagic coupling in an estuary ecosystem: consequences for microphytobenthos resuspension phenomenon. PLOS ONE 7:e44155.

Vander Zanden MJ, Rasmussen JB (2001) Variation in $\delta 15 \mathrm{~N}$ and $\delta 13 \mathrm{C}$ trophic fractionation: Implications for aquatic food web studies. Limnol Oceanogr 46:2061-2066.

Vanderklift MA, Ponsard S (2003) Sources of variation in consumer-diet $\delta 15 \mathrm{~N}$ enrichment: a meta-analysis. Oecologia 136:169-182. 
Vizzini S, Colombo F, Costa V, Mazzola A (2012) Contribution of planktonic and benthic food sources to the diet of the reef-forming vermetid gastropod Dendropoma petraeum in the western Mediterranean. Estuarine, Coastal and Shelf Science 96:262-267.

Watson GJ, Murray JM, Schaefer M, Bonner A, Gillingham M (2017) Assessing the impacts of bait collection on inter-tidal sediment and the associated macrofaunal and bird communities: The importance of appropriate spatial scales. Marine Environmental Research.

Wilson DP (1976) Sabellaria Alveolata (L.) At Duckpool, North Cornwall, 1975. Journal of the Marine Biological Association of the United Kingdom 56:305-310.

Wright JP, Jones CG, Flecker AS (2002) An ecosystem engineer, the beaver, increases species richness at the landscape scale. Oecologia 132:96-101.

van der Zee EM, Angelini C, Govers LL, Christianen MJA, Altieri AH, Reijden KJ van der, Silliman BR, Koppel J van de, Geest M van der, Gils JA van, Veer HW van der, Piersma T, Ruiter PC de, Olff H, Heide T van der (2016) How habitat-modifying organisms structure the food web of two coastal ecosystems. Proc R Soc B 283:20152326.

Zhao Q, Brink PJV den, Carpentier C, Wang YXG, Rodríguez-Sánchez P, Xu C, Vollbrecht S, Gillissen F, Vollebregt M, Wang S, Laender FD (2019) Horizontal and vertical diversity jointly shape food web stability against small and large perturbations. Ecology Letters 22:1152-1162. 


\section{Figures and tables}

Table 1. Species richness measured in the control sediments (CS), associated sediments (AS) and engineered sediments (ES) in winter (W) and summer (S) decomposed into taxonomic classes with the number left of the slash indicating the total consumer richness and the number right of the slash indicating the primary consumer richness. The species accounting for more than $1 \%$ of the total community biomass are also indicated with the asterisk designating secondary consumers. See Table S2 for the complete data.

\begin{tabular}{|c|c|c|c|c|c|c|c|c|}
\hline CS & $\mathbf{W}$ & $\mathbf{S}$ & AS & $\mathbf{W}$ & $\mathbf{S}$ & ES & $\mathbf{W}$ & $\mathbf{S}$ \\
\hline Polychaeta & $15 / 6$ & $15 / 6$ & Polychaeta & $11 / 7$ & $14 / 7$ & Polychaeta & $12 / 4$ & $12 / 3$ \\
\hline \multirow[t]{3}{*}{$\begin{array}{l}\text { Lanice } \\
\text { conchilega }\end{array}$} & $7.2 \%$ & $12.3 \%$ & $\begin{array}{l}\text { Cirriformia } \\
\text { tentaculata }\end{array}$ & $15.1 \%$ & $7.1 \%$ & $\begin{array}{l}\text { Sabellaria } \\
\text { alveolata }\end{array}$ & $57.8 \%$ & $22.7 \%$ \\
\hline & & & $\begin{array}{l}\text { Goniadella } \\
\text { bobrezkii* }\end{array}$ & $1.5 \%$ & $0.5 \%$ & & & \\
\hline & & & $\begin{array}{l}\text { Mediomastus } \\
\text { fragilis }\end{array}$ & $0.9 \%$ & $1.3 \%$ & & & \\
\hline Malacostraca & $13 / 3$ & $9 / 3$ & Malacostraca & $9 / 2$ & $9 / 2$ & Malacostraca & $11 / 3$ & $12 / 3$ \\
\hline \multirow[t]{2}{*}{$\begin{array}{l}\text { Carcinus } \\
\text { maenas* }\end{array}$} & $1.2 \%$ & $0.5 \%$ & $\begin{array}{l}\text { Carcinus } \\
\text { maenas* }\end{array}$ & $2.1 \%$ & $0.6 \%$ & $\begin{array}{l}\text { Carcinus } \\
\text { maenas* }\end{array}$ & $0.04 \%$ & $1.4 \%$ \\
\hline & & & & & & $\begin{array}{l}\text { Porcellana } \\
\text { platycheles }\end{array}$ & $4.5 \%$ & $19.4 \%$ \\
\hline Bivalvia & $9 / 9$ & $10 / 10$ & Bivalvia & $9 / 9$ & $10 / 10$ & Bivalvia & $7 / 7$ & $6 / 6$ \\
\hline $\begin{array}{l}\text { Cerastoderma } \\
\text { edule }\end{array}$ & $79.9 \%$ & $4.3 \%$ & $\begin{array}{l}\text { Magallana } \\
\text { gigas }\end{array}$ & - & $1.9 \%$ & $\begin{array}{l}\text { Magallana } \\
\text { gigas }\end{array}$ & $31.9 \%$ & $49.2 \%$ \\
\hline \multirow[t]{2}{*}{$\begin{array}{l}\text { Limecola } \\
\text { balthica }\end{array}$} & $4.4 \%$ & $80.9 \%$ & $\begin{array}{l}\text { Ruditapes } \\
\text { philippinarum * }\end{array}$ & $2.6 \%$ & $9.9 \%$ & $\begin{array}{l}\text { Mytilus cf. } \\
\text { galloprovincialis }\end{array}$ & $0.2 \%$ & $1.1 \%$ \\
\hline & & & $\begin{array}{l}\text { Venerupis } \\
\text { corrugata }\end{array}$ & $1.0 \%$ & $0.4 \%$ & & & \\
\hline Gastropoda & $2 / 1$ & $1 / 0$ & Gastropoda & $5 / 2$ & $3 / 1$ & Gastropoda & $8 / 5$ & $8 / 5$ \\
\hline $\begin{array}{l}\text { Tritia } \\
\text { reticulata* }\end{array}$ & $1.1 \%$ & $0.1 \%$ & $\begin{array}{l}\text { Crepidula } \\
\text { fornicata }\end{array}$ & $59.0 \%$ & $61.9 \%$ & $\begin{array}{l}\text { Crepidula } \\
\text { fornicata }\end{array}$ & $1.9 \%$ & $0.7 \%$ \\
\hline \multirow[t]{2}{*}{ Anthozoa } & $1 / 0$ & $0 / 0$ & Anthozoa & $1 / 0$ & $1 / 0$ & Anthozoa & $3 / 0$ & $2 / 0$ \\
\hline & & & $\begin{array}{l}\text { Cereus } \\
\text { pedunculatus* }\end{array}$ & $4.9 \%$ & $0.4 \%$ & & & \\
\hline Actinopterygii & $7 / 0$ & $7 / 0$ & Actinopterygii & $12 / 0$ & $5 / 0$ & Actinopterygii & $13 / 0$ & $6 / 0$ \\
\hline Ophiuroidea & $1 / 0$ & $2 / 1$ & Ophiuroidea & $0 / 0$ & $0 / 0$ & Ophiuroidea & $0 / 0$ & $0 / 0$ \\
\hline Pycnogonida & $1 / 0$ & $0 / 0$ & Pycnogonida & $0 / 0$ & $0 / 0$ & Pycnogonida & $2 / 0$ & $1 / 0$ \\
\hline \multirow[t]{2}{*}{ Sipunculidea } & $0 / 0$ & $0 / 0$ & Sipunculidea & $3 / 3$ & $2 / 2$ & Sipunculidea & $3 / 3$ & $3 / 3$ \\
\hline & & & $\begin{array}{l}\text { Golfingia } \\
\text { vulgaris }\end{array}$ & $6.0 \%$ & $2.6 \%$ & & & \\
\hline Ascidiacea & $0 / 0$ & $0 / 0$ & Ascidiacea & $0 / 0$ & $1 / 1$ & Ascidiacea & $2 / 2$ & $3 / 3$ \\
\hline Other & $0 / 0$ & $0 / 0$ & Other & $0 / 0$ & $0 / 0$ & Other & $3 / 1$ & $4 / 2$ \\
\hline Total & $49 / 19$ & $44 / 26$ & Total & $50 / 20$ & $45 / 23$ & Total & $64 / 25$ & $57 / 25$ \\
\hline
\end{tabular}


Table 2. (a) Community-wide metrics (number of sampled consumer species, total area of the convex hull, and standard ellipse area) calculated for the three sediment type consumer communities (control, associated, and engineered) in winter and summer, using the mean consumer isotopic compositions. The probability comparing the Bayesian SEA of each consumer community between the winter and summer sampling and the corresponding SEA overlaps are also indicated. (b) Two-by-two probability comparing the Bayesian SEA of each consumer community in winter and summer and the corresponding SEA overlaps. For example, the values 0.83 and 0.71 for the Bayesian probabilities SEA (CS) < SEA (ES) in winter and summer mean that there is an $83 \%$ and $71 \%$ chance that the CS isotopic niche is smaller than the ES isotopic niche in winter and summer, respectively.

\begin{tabular}{|c|c|c|c|c|c|c|c|c|}
\hline (a) & & Wir & & & Sum & & Probability SEA & SEA \\
\hline $\begin{array}{l}\text { Consumer } \\
\text { community }\end{array}$ & $\mathbf{n}$ & $\begin{array}{l}\text { TA } \\
\left(\% 0^{2}\right)\end{array}$ & $\begin{array}{l}\text { SEA } \\
\left(\%{ }^{2}\right)\end{array}$ & $\mathbf{n}$ & $\begin{array}{l}\text { TA } \\
\left(\% 0^{2}\right)\end{array}$ & $\begin{array}{l}\text { SEA } \\
\left(\%{ }^{2}\right)\end{array}$ & $\begin{array}{c}\text { (winter) }<\text { SEA } \\
(\text { summer })\end{array}$ & $\begin{array}{c}\text { overlap } \\
(\%)\end{array}$ \\
\hline CS & 42 & 33.99 & 8.94 & 42 & 34.80 & 10.51 & 0.76 & 92.43 \\
\hline $\mathbf{A S}$ & 42 & 31.36 & 9.20 & 43 & 54.93 & 12.09 & 0.89 & 85.75 \\
\hline ES & 57 & 42.39 & 11.02 & 54 & 53.19 & 11.77 & 0.65 & 93.36 \\
\hline
\end{tabular}

(b)

Winter

Summer

\begin{tabular}{lcccc}
\hline $\begin{array}{l}\text { Consumer } \\
\text { community }\end{array}$ & $\begin{array}{c}\text { Bayesian } \\
\text { probability SEA } \\
\text { a - b }\end{array}$ & SEA overlap (\%) & $\begin{array}{c}\text { Probability SEA } \\
(\mathbf{a})<\text { SEA (b) }\end{array}$ & SEA overlap (\%) \\
\hline CS - AS & 0.54 & 77.03 & 0.75 & 61.50 \\
\hline CS - ES & 0.83 & 78.40 & 0.71 & 63.33 \\
\hline AS - ES & 0.79 & 95.00 & 0.44 & 86.17
\end{tabular}

n, number of sampled consumer species; TA, total area of the convex hull; SEA, standard ellipse area;

CS, control sediments; AS, associated sediments; ES, engineered sediments 
Table 3. Mean and standard deviations [2.5-97.5\% confidence intervals] of the relative contribution (\%) of the two or three basal resources to the assimilated diet of all the primary consumers sampled in each sediment type in winter and summer, estimated using Bayesian mixing models. The overall mean dietary contribution of benthic organic matter sources is equal to the microphytobenthos dietary contribution in the control sediments and to the sum of the mean microphytobenthos and Ulva spp. contributions in the associated and engineered sediments.

\begin{tabular}{lllllll}
\hline & Winter & \multicolumn{5}{c}{ Summer } \\
\hline CS & AS & ES & CS & AS & ES \\
\hline POM & 185 & 87 & 352 & 141 & 107 & 348 \\
\hline MPB & $10.0 \pm 2.3$ & $39.2 \pm 3.5$ & $23.5 \pm 2.5$ & $12.1 \pm 2.7$ & $52.4 \pm 3.1$ & $40.2 \pm 2.5$ \\
& {$[5.6-14.6]$} & {$[32.3-46.0]$} & {$[18.7-28.3]$} & {$[6.9-17.5]$} & {$[46.2-58.5]$} & {$[35.2-45.0]$} \\
\hline Ulva spp. & $90.0 \pm 2.3$ & $53.2 \pm 4.9$ & $50.9 \pm 3.8$ & $87.9 \pm 2.7$ & $33.0 \pm 5.4$ & $30.2 \pm 3.6$ \\
& {$[85.4-94.4]$} & {$[43.4-62.6]$} & {$[43.5-58.4]$} & {$[82.5-93.1]$} & {$[22.4-43.5]$} & {$[23.2-37.2]$} \\
\hline Benthic basal & & $7.6 \pm 2.5$ & $25.5 \pm 2.2$ & & $14.6 \pm 3.3$ & $29.6 \pm 1.9$ \\
resources & 90.0 & {$[2.8-12.8]$} & {$[21.3-29.8]$} & & {$[8.1-21.2]$} & {$[26.0-33.4]$} \\
\hline
\end{tabular}

$\overline{\mathrm{CS} \text {, control sediments; AS, associated sediments; ES, engineered sediments; POM, particulate organic }}$ matter; MPB: microphytobenthos 



Fig. 1. Carbon and nitrogen isotopic composition $\left(\delta^{13} \mathrm{C}\right.$ and $\delta^{15} \mathrm{~N}, \%$ ) of the consumer species (round symbols) and basal resources (white squares) sampled in the control (CS), associated (AS), and engineered (ES) sediments. The mean and standard deviations of the basal resources (particulate organic matter (POM), sediment organic matter (SOM), microphytobenthos (MPB), Ulva spp. (ULV)) are calculated as annual averages. For consumers, mean $\delta^{13} \mathrm{C}$ and $\delta^{15} \mathrm{~N}$ values are represented without error bars for clarity. The gray round symbols are proportional to the relative contribution of each species to 
the total biomass in each sediment type (contributions $>1 \%$, species names are labeled) and the other round symbols indicate a relative contribution $<1 \%$. The species displaying extreme $\delta^{13} \mathrm{C}$ and $\delta^{15} \mathrm{~N}$ values are also labelled (white round symbols). In the winter AS biplot, there is a confusion between the Venerupis corrugata and Ruditapes philippinarum symbols as their respective $\delta^{13} \mathrm{C}$ and $\delta^{15} \mathrm{~N}$ values are almost identical. 

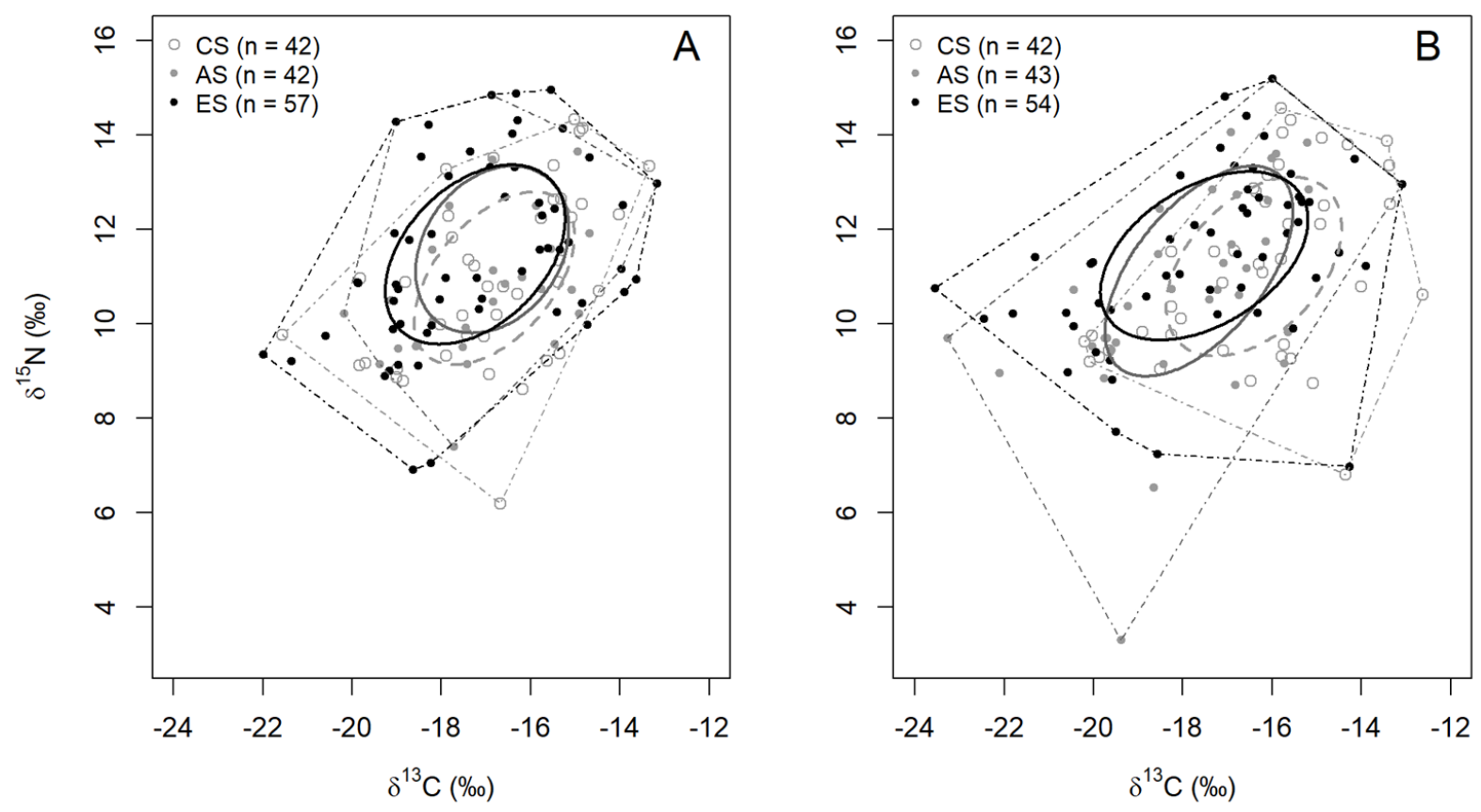

Fig. 2. Biplot of the mean carbon and nitrogen isotopic compositions $\left(\delta^{13} \mathrm{C}\right.$ and $\delta^{15} \mathrm{~N}, \%$ of the consumers sampled in the control sediments (CS), associated sediments (AS) and engineered sediments (ES) in (A) winter and (B) summer. The dashed light gray ellipse encloses the standard ellipse area (SEA) of the CS consumer community. The solid dark gray and black ellipses respectively enclose the SEA of the AS and ES consumer communities. The dotted and dashed lines represent the total isotopic niche width of each of the consumer communities, using the same color code as for the SEA. 

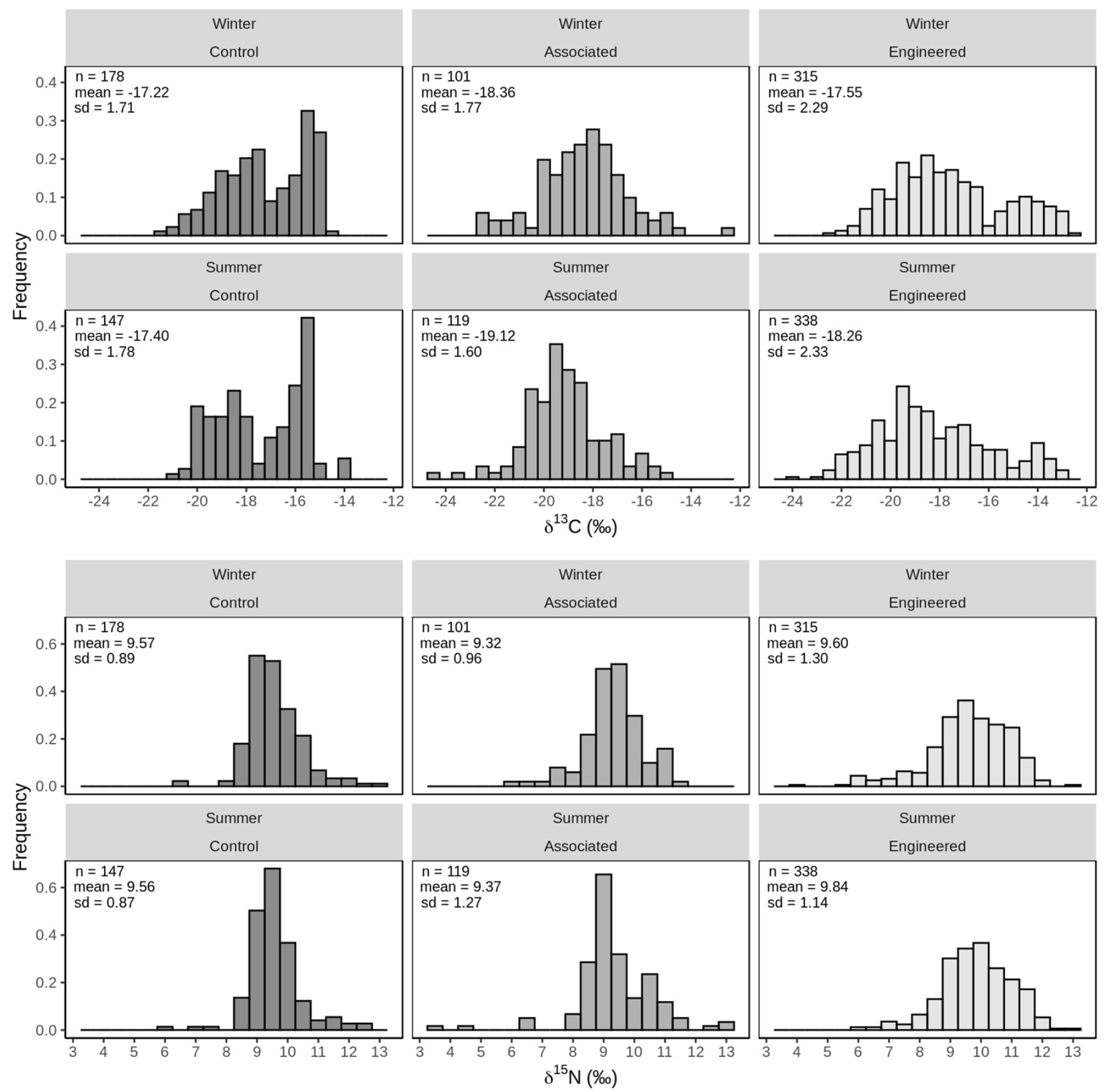

Fig. 3. Frequency distributions of carbon (top) and nitrogen (bottom) isotopic compositions $\left(\delta^{13} \mathrm{C}\right.$ and $\delta^{15} \mathrm{~N}, \%$ ) of all the primary consumers sampled in the control, associated and engineered sediments in winter and summer with the associated sample sizes (n), mean values and standard deviations (SD). A size class of $0.5 \%$ was used for both $\delta^{13} \mathrm{C}$ and $\delta^{15} \mathrm{~N}$. 

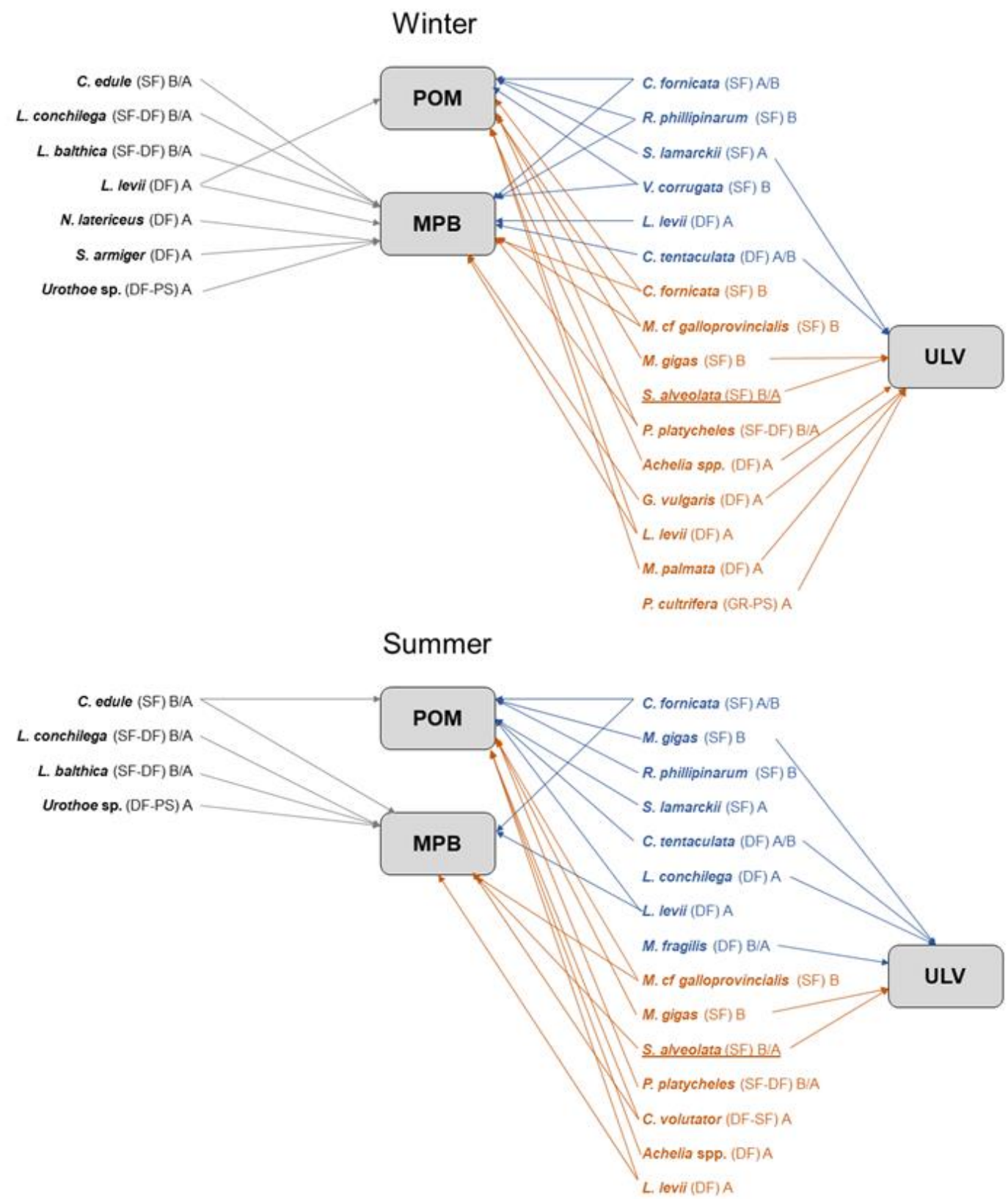

Fig. 4. Basal resources (particulate organic matter (POM), microphytobenthos (MPB), Ulva spp. (ULV)) contributing more than $30 \%$ to the assimilated diet of the primary consumers that account for over $1 \%$ of the total biomass (B) and/or over $1 \%$ of the total abundance (A) in the control sediments (black), associated sediments (blue) and engineered sediments (orange) in winter (top) and summer (bottom), as calculated by the stable isotope mixing models. The feeding mode of each species is specified as suspension-feeder (SF), deposit-feeder (DF), predator-scavenger (PS) and/or grazer (GR), and the engineer species Sabellaria alveolata is underlined. Figure adapted from Jankowska et al. (2018). 


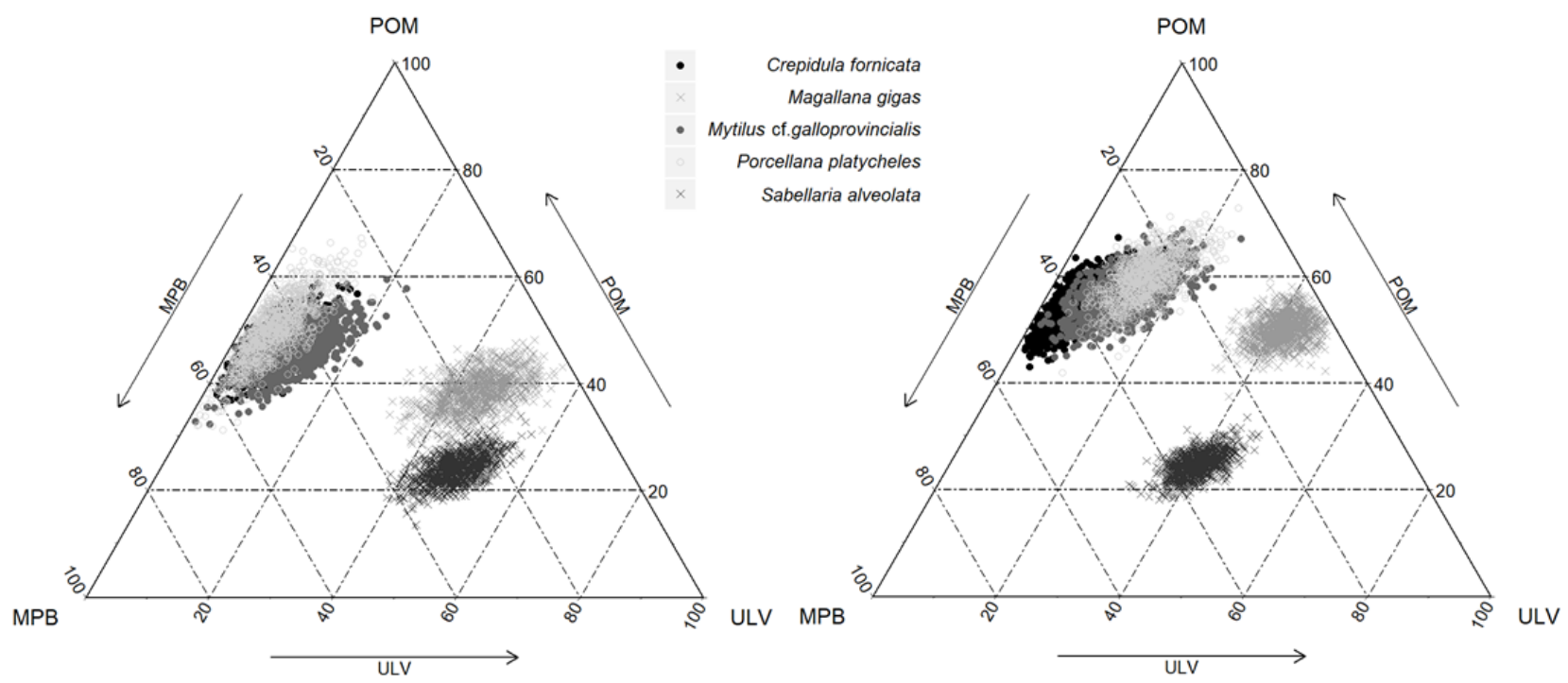

Fig. 5. Ternary plots of the relative contributions of particulate organic matter (POM), microphytobenthos (MPB) and Ulva spp. (ULV) to the assimilated diet of the engineer species Sabellaria alveolata and four abundant suspension-feeders co-occurring in the engineered sediments (Magallana gigas, Mytilus cf. galloprovincialis, Crepidula fornicata and Porcellana platycheles) in winter (left) and summer (right). Each point represents the posterior dietary proportions calculated by the stable isotope mixing model using the $\delta^{13} \mathrm{C}$ and $\delta^{15} \mathrm{~N}$ measured for each organism. As an illustration, the assimilated summer diet of $S$. alveolata is composed of $c a .40 \% \mathrm{ULV}, 35 \% \mathrm{MPB}$ and $25 \%$ POM. 


\section{Supplementary material}

S1. Protocol used to extract the MPB from the sampled sediments.

To extract the MPB from the sediment, we used liquid silica (LUDOX HS-30). The sampled sediment was defrosted in a refrigerator, then $5 \mathrm{ml}$ of homogenized sediment was placed into a $50 \mathrm{~mL}$ falcon (A) and $25 \mathrm{~mL}$ of LUDOX HS-30 were added. The flacon tubes were then mixed, placed into an ultrasound bath for $15 \mathrm{~min}$ and mixed again. After, they were centrifuged at 5000 rpm for $15 \mathrm{~min}$ at $10^{\circ} \mathrm{C}$ and the supernatant containing the MPB was placed into another falcon using a clean pipet (B). All the steps between A and B were repeated three times for each 50 $\mathrm{ml}$ falcon tube. In the end we had a new falcon tube containing a mix of MPB and liquid silica that we rinsed using MilliQ water and the dilution 3 MilliQ water for 1 supernatant. The falcon containing the supernatant and the MilliQ water was centrifuged at $3500 \mathrm{rpm}$ for $10 \mathrm{~min}$ at $10^{\circ} \mathrm{C}$, the resultant supernatant was removed and the rest was placed at $-80^{\circ} \mathrm{C}$ until further processing. 
Table S2. Carbon and nitrogen isotope ratios $\left(\delta^{13} \mathrm{C}\right.$ and $\left.\delta^{15} \mathrm{~N}\right)$, with the corresponding standard deviations (SD), of the different macroinvertebrate and vertebrate species sampled in the control, associated and engineered sediments in winter and summer. The relative biomass contribution of each species to the total biomass sampled in each sediment is indicated as \% biom and the species accounting for more than $1 \%$ of the total biomass are in bold. The vertebrate species indicated in the engineered sediment section were sampled in the reef zone and were represented on the engineered and associated sediment isotopic biplots (Fig. 1). Some species were only sampled in the cores used for the isotopic analysis and not in the ones used for the biomass estimations. Hence, we could not estimate their biomass which is indicated by (-). The species marked with a * were strict primary consumers and used to build Figure 3 while species marked with \# were partial primary consumers and additionally considered to build Figure 4 and Table 2.

\begin{tabular}{|c|c|c|c|c|c|c|c|c|c|c|}
\hline Control sediment & Winter & & & & & Summer & & & & \\
\hline & $\delta^{13} \mathrm{C}$ & SD & $\delta^{15} \mathrm{~N}$ & $\mathrm{SD}$ & $\begin{array}{c}\% \\
\text { biom }\end{array}$ & $\delta^{13} \mathrm{C}$ & $\mathrm{SD}$ & $\delta^{15} \mathrm{~N}$ & $\mathrm{SD}$ & $\%$ biom \\
\hline Polychaeta & & & & & & & & & & \\
\hline $\begin{array}{l}\text { Armandia } \\
\text { polyophthalma* }\end{array}$ & -15.76 & NA & 12.23 & NA & 0.04 & -15.80 & NA & 11.36 & NA & $(-)$ \\
\hline Caulleriella alata* & -17.53 & 0.38 & 10.17 & 0.19 & $(-)$ & - & - & - & - & $<0.01$ \\
\hline Eumida sanguinea & -16.83 & 0.47 & 13.51 & 0.32 & 0.04 & -18.25 & 0.42 & 11.53 & 0.97 & 0.01 \\
\hline Eunereis longissima & -16.62 & NA & 10.78 & NA & $(-)$ & -15.58 & NA & 14.31 & NA & 0.09 \\
\hline Glycera alba & -14.84 & 1.02 & 14.13 & 0.11 & 0.10 & -14.89 & 0.62 & 13.93 & 0.65 & 0.09 \\
\hline Glycera tridactyla & -14.90 & 0.33 & 14.07 & 0.33 & $(-)$ & - & - & - & - & - \\
\hline Goniadella bobrezkii & - & - & - & - & $<0.01$ & -16.36 & NA & 12.79 & NA & $<0.01$ \\
\hline Lanice conchilega* & -16.85 & 0.27 & 11.53 & 0.29 & 7.23 & -17.26 & 0.42 & 11.23 & 0.31 & 12.35 \\
\hline Magelona johnstoni* & -17.42 & NA & 9.76 & NA & 0.01 & - & - & - & - & $<0.01$ \\
\hline $\begin{array}{l}\text { Malmgrenia } \\
\text { arenicolae }\end{array}$ & -17.84 & NA & 12.28 & NA & 0.09 & -16.15 & 0.40 & 12.58 & 0.27 & 0.21 \\
\hline Nephtys cirrosa & - & - & - & - & 1.34 & -14.92 & 0.45 & 12.11 & 0.67 & 0.18 \\
\hline Nephtys hombergii & -15.09 & 0.68 & 12.24 & 0.62 & 1.05 & -15.63 & 1.34 & 12.10 & 0.51 & 0.35 \\
\hline Notomastus sp. ${ }^{*}$ & -17.10 & $<0.01$ & 9.43 & 0.28 & 0.28 & -16.76 & 0.10 & 10.19 & 0.38 & 0.28 \\
\hline Pholoe inornata & - & - & - & - & - & -17.29 & NA & 11.52 & NA & $<0.01$ \\
\hline Phyllodoce тисоsa & - & - & - & - & - & -18.04 & NA & 10.11 & NA & 0.01 \\
\hline Scolelepis armiger* & -15.49 & 0.74 & 12.62 & 0.64 & 0.11 & -16.21 & 0.85 & 11.08 & 1.36 & 0.01 \\
\hline Sthenelais boa & -15.49 & 0.44 & 13.35 & 0.95 & $(-)$ & - & - & - & - & - \\
\hline
\end{tabular}




\begin{tabular}{|c|c|c|c|c|c|c|c|c|c|c|}
\hline \multicolumn{11}{|l|}{ Malacostraca } \\
\hline Anapagurus sp. & -18.80 & NA & 10.88 & NA & 0.03 & - & - & - & - & - \\
\hline Carcinus maenas & -17.39 & $\mathbf{0 . 8 7}$ & 11.34 & 0.67 & 1.19 & -16.29 & 0.77 & 11.26 & 0.73 & 0.49 \\
\hline Crangon crangon & -13.34 & 0.43 & 13.33 & 0.20 & $<0.01$ & -13.36 & 0.48 & 12.53 & 0.35 & $<0.01$ \\
\hline Diogenes pugilator & -16.93 & 0.80 & 8.92 & 0.45 & $<0.01$ & -20.08 & 2.54 & 9.20 & 0.90 & $<0.01$ \\
\hline Gammarus zaddachi\# & -19.84 & 0.33 & 9.12 & 0.45 & $(-)$ & - & - & - & - & - \\
\hline Idotea linearis & -17.89 & 0.64 & 9.31 & 0.26 & $(-)$ & - & - & - & - & - \\
\hline Lekanesphaera levii* & -16.67 & 4.34 & 6.19 & 0.72 & 0.06 & -14.35 & 0.57 & 6.80 & 0.65 & 0.01 \\
\hline $\begin{array}{l}\text { Lekanesphaera } \\
\text { rugicauda* }\end{array}$ & - & - & - & - & 0.01 & -15.08 & NA & 8.73 & NA & $<0.01$ \\
\hline Liocarcinus holsatus & - & - & - & - & - & -17.12 & 1.50 & 10.86 & 0.57 & $<0.01$ \\
\hline Liocarcinus sp. & -16.96 & NA & 10.78 & NA & $(-)$ & - & - & - & - & - \\
\hline Macropodia linaresi & -21.56 & NA & 9.76 & NA & $(-)$ & - & - & - & - & - \\
\hline Palaemon serratus & - & - & - & - & - & -16.42 & 0.86 & 12.87 & 0.17 & $<0.01$ \\
\hline Portumnus latipes & - & - & - & - & 0.4 & -14.01 & 1.13 & 10.78 & 1.07 & 0.03 \\
\hline Urothoe poseidonis* & -15.39 & 0.33 & 10.88 & 1.13 & $<0.01$ & -15.73 & 1.58 & 9.56 & 1.24 & $<0.01$ \\
\hline \multicolumn{11}{|l|}{ Bivalvia } \\
\hline Abra alba* & -16.18 & 0.60 & 8.61 & 0.19 & 0.02 & -16.48 & 0.23 & 8.79 & 0.26 & 0.10 \\
\hline Cerastoderma edule* & -18.03 & 0.82 & 9.97 & 0.56 & 79.88 & -18.91 & 0.75 & 9.82 & 0.47 & 4.29 \\
\hline $\begin{array}{l}\text { Cerastoderma } \\
\text { glaucum* }\end{array}$ & - & - & - & - & - & -18.25 & NA & 10.35 & NA & 0.03 \\
\hline Limecola balthica* & -15.35 & 0.30 & 9.36 & 0.45 & 4.43 & -15.58 & $\mathbf{0 . 3 1}$ & 9.26 & 0.66 & 80.87 \\
\hline $\begin{array}{l}\text { Macomangulus } \\
\text { tenuis* }\end{array}$ & -15.63 & 0.40 & 9.22 & 0.40 & 0.04 & -15.78 & 0.33 & 9.31 & 0.41 & 0.19 \\
\hline $\begin{array}{l}\text { Mytilus cf. } \\
\text { galloprovincialis* }\end{array}$ & -19.70 & 0.81 & 9.15 & 0.31 & 0.73 & -19.87 & 0.55 & 9.28 & 0.57 & 0.15 \\
\hline Mytilus edulis* & -20.20 & 0.32 & 9.62 & 0.19 & 0.01 & - & - & - & - & $<0.01$ \\
\hline $\begin{array}{l}\text { Ruditapes } \\
\text { philippinarum* }\end{array}$ & -18.98 & 0.38 & 9.04 & 0.09 & 0.14 & -19.65 & 0.34 & 9.42 & 0.16 & 0.04 \\
\hline Spisula solida* & -17.05 & NA & 9.73 & NA & $<0.01$ & -18.25 & 0.27 & 9.75 & 0.24 & 0.01 \\
\hline Venerupis corrugata* & -18.86 & 0.91 & 8.78 & 0.49 & 0.01 & -20.04 & 0.10 & 9.74 & 0.24 & $<0.01$ \\
\hline \multicolumn{11}{|l|}{ Gastropoda } \\
\hline Crepidula fornicata* & -19.00 & 0.92 & 8.86 & 0.26 & 0.25 & - & - & - & - & - \\
\hline Tritia reticulata & -14.85 & 0.42 & 12.53 & 0.33 & 1.09 & -14.83 & 0.37 & 12.50 & 0.34 & 0.15 \\
\hline \multicolumn{11}{|l|}{ Anthozoa } \\
\hline Cereus pedunculatus & -14.01 & 0.34 & 12.31 & 0.09 & 0.04 & - & - & - & - & - \\
\hline \multicolumn{11}{|l|}{ Ophiuroidea } \\
\hline $\begin{array}{l}\text { Acrocnida } \\
\text { spatulispina }\end{array}$ & - & - & - & - & 0.79 & -16.09 & NA & 13.15 & NA & $(-)$ \\
\hline $\begin{array}{l}\text { Amphipholis } \\
\text { squamata* }\end{array}$ & - & - & - & - & - & -18.51 & NA & 9.03 & NA & $(-)$ \\
\hline \multicolumn{11}{|l|}{ Pycnogonida } \\
\hline Nymphon brevirostre & -19.82 & NA & 10.96 & NA & $(-)$ & - & - & - & - & - \\
\hline Actinopterygii & & & & & & & & & & \\
\hline
\end{tabular}


Hippocampus

hippocampus

\begin{tabular}{lcccccccccc}
\hline Liza aurata & -15.35 & 0.49 & 11.34 & 0.44 & $<0.01$ & -12.62 & 0.66 & 10.62 & 1.92 & $<0.01$ \\
\hline Liza ramada & -16.30 & NA & 10.63 & NA & $<0.01$ & - & - & - & - & - \\
\hline Pleuronectes platessa & -15.31 & NA & 12.64 & NA & $<0.01$ & -13.38 & 0.75 & 13.35 & 0.69 & $<0.01$ \\
\hline Pomatoschistus spp. & -15.02 & 0.33 & 14.32 & 0.12 & 0.01 & -15.76 & 0.37 & 14.05 & 0.38 & $<0.01$ \\
\hline Solea vulgaris & - & - & - & - & - & -14.30 & 0.46 & 13.79 & 0.44 & 0.02 \\
\hline Trachinus vipera & -17.90 & NA & 13.27 & NA & $<0.01$ & -15.85 & NA & 13.37 & NA & $<0.01$ \\
\hline Triglia lucerna & - & - & - & - & - & -13.42 & 0.18 & 13.87 & 0.26 & $<0.01$ \\
\hline Trisopterus luscus & -14.47 & 0.69 & 10.68 & 1.21 & 0.12 & -15.81 & 0.45 & 14.56 & 0.22 & $<0.01$
\end{tabular}

\section{Associated sediments}

\section{Winter}

$\delta^{13} \mathrm{C}$

\section{Summer}

biom

SD $\quad \delta^{15} \mathrm{~N} \quad \mathrm{SD}$

\section{Polychaeta}

\begin{tabular}{|c|c|c|c|c|c|c|c|c|c|c|}
\hline Armandia polyophthalma* & -17.46 & NA & 9.92 & NA & $(-)$ & - & - & - & - & - \\
\hline Cirriformia tentaculata* & -16.84 & 0.35 & 10.47 & 0.56 & 15.11 & -18.56 & 0.78 & 11.47 & 1.06 & 7.14 \\
\hline Glycera alba & -14.95 & NA & 13.64 & NA & 0.85 & -16.01 & 0.18 & 13.51 & 0.65 & 0.15 \\
\hline Goniadella bobrezkii & -16.85 & 0.77 & 13.47 & 1.06 & 1.48 & -16.93 & 0.59 & 14.05 & 0.72 & 0.46 \\
\hline Lanice conchilega* & -18.20 & NA & 11.57 & NA & $(-)$ & -17.09 & 0.36 & 11.29 & 0.25 & 0.91 \\
\hline Mediomastus fragilis* & - & - & - & - & 0.9 & -17.40 & 0.33 & 10.52 & 0.78 & 1.30 \\
\hline Malmgrenia arenicolae & 17.83 & NA & 12.50 & NA & 0.05 & -15.19 & NA & 12.84 & NA & 0.04 \\
\hline Nephtys cirrosa & - & - & - & - & - & -15.22 & NA & 13.84 & NA & 0.36 \\
\hline Nephtys hombergii & - & - & - & - & - & -16.14 & 0.58 & 11.74 & 1.21 & 0.87 \\
\hline Notomastus laterice & 16.58 & 0.27 & 10.84 & 0.00 & 0.03 & - & - & - & - & 0.1 \\
\hline Orbinia sp.* & - & - & - & - & - & -17.23 & NA & 10.72 & NA & $(-)$ \\
\hline Perinereis cultrifera & -14.69 & 0.86 & 11.92 & 0.37 & 0.55 & -18.52 & NA & 12.43 & NA & $<0.01$ \\
\hline Saccocirrus papillocercus* & -20.19 & NA & 10.22 & NA & $<0.01$ & - & - & - & - & 2.16 \\
\hline Spirobranchus lamarckii* & 19.14 & 0.62 & 10.49 & 0.57 & 0.43 & -20.45 & 0.44 & 10.72 & 0.30 & 0.16 \\
\hline Websterinereis glauca & - & - & - & - & - & -15.91 & 1.13 & 13.60 & 1.24 & $<0.01$ \\
\hline \multicolumn{11}{|l|}{ Malacostraca } \\
\hline Athanas nitescens & - & - & - & - & 0.05 & -17.34 & NA & 12.85 & NA & $(-)$ \\
\hline Carcinus maenas & -16.85 & 0.94 & 11.14 & 1.10 & 2.07 & -16.74 & 0.86 & 10.61 & 1.19 & 0.61 \\
\hline Crangon crangon & -13.18 & 0.58 & 12.97 & 0.57 & 0.02 & -13.09 & 0.59 & 12.96 & 0.23 & $<0.01$ \\
\hline Lekanesphaera levii* & -17.73 & 1.60 & 7.40 & 0.77 & 0.53 & -18.65 & 1.18 & 6.54 & 1.19 & 0.55 \\
\hline Lekanesphaera rugicauda* & - & - & - & - & 0.03 & -19.38 & NA & 3.30 & NA & 0.10 \\
\hline Liocarcinus holsatus & -18.72 & NA & 11.78 & NA & $(-)$ & -18.29 & NA & 11.79 & NA & $<0.01$ \\
\hline Macropodia parva & - & - & - & - & - & -20.63 & 0.37 & 10.24 & 0.63 & $<0.01$ \\
\hline Melita palmata & - & - & - & - & 0.05 & -22.12 & 1.33 & 8.96 & 0.46 & $<0.01$ \\
\hline Palaemon serratus & -15.81 & 1.11 & 12.56 & 0.32 & 0.01 & -15.58 & 0.44 & 13.18 & 0.43 & $<0.01$ \\
\hline Processa edulis & -19.05 & NA & 11.92 & NA & $<0.01$ & - & - & - & - & - \\
\hline \multicolumn{11}{|l|}{ Bivalvia } \\
\hline Abra alba* & - & - & - & - & $<0.01$ & -16.83 & NA & 8.70 & NA & 0.02 \\
\hline Cerastoderma edule* & -17.53 & 1.28 & 9.50 & 0.15 & 0.29 & -19.50 & 0.28 & 9.60 & 0.20 & 0.06 \\
\hline
\end{tabular}




\begin{tabular}{|c|c|c|c|c|c|c|c|c|c|c|}
\hline Limecola balthica* & -15.47 & 0.64 & 9.58 & 0.56 & $<0.01$ & -15.73 & 0.32 & 9.16 & 0.29 & 0.90 \\
\hline Magallana gigas* & - & - & - & - & - & -18.26 & 0.49 & 10.74 & 0.38 & 1.86 \\
\hline Mytilus cf. galloprovincialis* & -18.97 & 0.56 & 9.47 & 0.29 & 0.68 & -19.61 & NA & 9.45 & NA & 0.90 \\
\hline Polititapes rhomboides $*$ & -18.20 & 0.01 & 10.08 & 0.15 & 0.18 & - & - & - & - & - \\
\hline Ruditapes decussatus* & - & - & - & - & 0.76 & -19.70 & 0.42 & 9.70 & $\mathbf{0 . 8 1}$ & 3.95 \\
\hline Ruditapes philippinarum* & -18.55 & 0.46 & 9.57 & 0.27 & 2.62 & -20.03 & 0.80 & 9.53 & 0.55 & 9.94 \\
\hline Spisula solida* & -17.43 & 0.54 & 9.14 & 0.39 & 0.57 & -18.44 & 1.06 & 9.15 & 0.13 & 0.12 \\
\hline Venerupis corrugata* & -18.58 & 1.42 & 9.52 & 0.54 & 1.01 & -19.75 & 0.70 & 9.70 & 0.56 & 0.38 \\
\hline Venus verrucosa* & - & - & - & - & - & -19.23 & 0.34 & 10.37 & 0.47 & 0.20 \\
\hline \multicolumn{11}{|l|}{ Gastropoda } \\
\hline Crepidula fornicata $*$ & -19.38 & 1.65 & 9.15 & $\mathbf{0 . 5 0}$ & 59.00 & -19.77 & 1.36 & 8.85 & 0.31 & 61.95 \\
\hline Nucella lapilus & -16.20 & NA & 10.98 & NA & 0.17 & - & - & - & - & - \\
\hline Ocenebra erinaceus & - & - & - & - & 0.03 & -16.92 & 0.39 & 11.68 & 0.69 & 0.05 \\
\hline Steromphala umbilicalis* & -15.77 & 4.53 & 10.74 & 0.68 & 0.06 & - & - & - & - & - \\
\hline Tritia reticulata & -15.88 & 1.42 & 12.50 & 0.51 & 0.11 & -16.09 & 0.30 & 12.61 & 0.34 & 0.80 \\
\hline \multicolumn{11}{|l|}{ Anthozoa } \\
\hline Cereus pedunculatus & -15.55 & 0.98 & 11.58 & 1.13 & 4.91 & -16.80 & 0.76 & 12.74 & 0.37 & 0.38 \\
\hline \multicolumn{11}{|l|}{ Sipunculidea } \\
\hline Golfingia elongata* & -14.92 & NA & 10.22 & NA & 0.18 & - & - & - & - & - \\
\hline Golfingia vulgaris* & -15.09 & 0.49 & 10.73 & 0.71 & 5.99 & -15.65 & 0.46 & 9.82 & 0.70 & 2.63 \\
\hline Nephasoma minutum* & - & - & - & - & 0.12 & -16.58 & NA & 11.18 & NA & 0.03 \\
\hline \multicolumn{11}{|l|}{ Ascidiacea } \\
\hline Styela clava* & - & - & - & - & - & -23.27 & NA & 9.69 & NA & $(-)$ \\
\hline
\end{tabular}

\begin{tabular}{|c|c|c|c|c|c|c|c|c|c|c|}
\hline \multirow[t]{2}{*}{ Engineered sediment } & \multicolumn{5}{|l|}{ Winter } & \multicolumn{5}{|c|}{ Summer } \\
\hline & $\delta^{13} \mathrm{C}$ & SD & $\delta^{15} \mathrm{~N}$ & SD & $\%$ biom & $\delta^{13} \mathrm{C}$ & SD & $\delta^{15} \mathrm{~N}$ & SD & $\%$ biom \\
\hline \multicolumn{11}{|l|}{ Polychaeta } \\
\hline Audomimia tentaculata & -17.16 & NA & 10.31 & NA & $(-)$ & - & - & - & - & $\begin{array}{c}- \\
-\end{array}$ \\
\hline Eulalia ornata & - & - & - & - & $<0.01$ & -16.66 & 0.14 & 12.46 & 0.32 & 0.03 \\
\hline Eulalia viridis & -16.30 & 0.85 & 14.31 & 0.93 & 0.09 & -17.16 & 1.55 & 13.72 & 1.32 & 0.21 \\
\hline Eumida sanguinea & - & - & - & - & $<0.01$ & -16.84 & 0.31 & 13.35 & 0.50 & 0.01 \\
\hline Malmgrenia arenicolae & - & - & - & - & - & -15.65 & NA & 12.52 & NA & $(-)$ \\
\hline Mediomastus fragilis* & - & - & - & - & $<0.01$ & -16.70 & NA & 10.77 & NA & $<0.01$ \\
\hline Nephtys hombergii & - & - & - & - & - & -15.34 & NA & 12.58 & NA & $(-)$ \\
\hline Odontosyllis ctenostoma & -19.89 & 0.51 & 10.88 & 0.88 & $<0.01$ & -20.08 & 0.63 & 11.28 & 0.12 & 0.02 \\
\hline Perinereis cultrifera\# & -15.61 & 1.32 & 11.61 & 0.83 & 0.38 & -17.74 & 1.74 & 12.09 & 0.54 & 0.35 \\
\hline Phyllodoce laminosa & - & - & - & - & $<0.01$ & -16.43 & 0.20 & 13.31 & 0.47 & 0.43 \\
\hline Sabellaria alveolata* & -17.09 & 0.55 & 10.54 & 0.65 & $\mathbf{5 7 . 8 5}$ & -17.23 & 0.48 & 10.19 & 0.52 & 22.66 \\
\hline Serpula vermicularis* & -21.37 & NA & 9.21 & NA & $(-)$ & - & - & - & - & - \\
\hline Spirobranchus lamarckii* & -19.88 & 0.72 & 10.85 & 0.71 & 0.01 & -20.03 & 0.95 & 11.30 & 0.24 & 0.05 \\
\hline Syllis gracilis & -16.91 & NA & 13.32 & NA & $<0.01$ & - & - & - & - & $<0.01$ \\
\hline \multicolumn{11}{|l|}{ Malacostraca } \\
\hline Carcinus maenas & -17.22 & 0.71 & 10.98 & 0.53 & 0.04 & -17.39 & 1.23 & 10.72 & 0.88 & 1.37 \\
\hline
\end{tabular}




\begin{tabular}{|c|c|c|c|c|c|c|c|c|c|c|}
\hline Corophium volutator* & -18.23 & 1.10 & 7.05 & 0.76 & $<0.01$ & - & - & - & - & - \\
\hline Corophium sp. ${ }^{*}$ & - & - & - & - & - & -18.58 & 0.53 & 7.25 & 0.44 & 0.03 \\
\hline Crangon crangon & -13.18 & 0.58 & 12.97 & 0.58 & $<0.01$ & -13.09 & 0.59 & 12.96 & 0.23 & $<0.01$ \\
\hline Diogenes pugilator & - & - & - & - & - & -18.07 & NA & 11.05 & NA & $<0.01$ \\
\hline Gnathia maxillaris & -17.92 & 0.77 & 10.97 & 2.97 & $<0.01$ & -16.54 & NA & 12.85 & NA & 0.01 \\
\hline Jassa ocia & -18.52 & NA & 9.11 & NA & $<0.01$ & - & - & - & - & $<0.01$ \\
\hline Lekanesphaera levii* & -18.65 & 1.58 & 6.91 & 1.00 & 0.25 & -19.50 & 1.81 & 7.71 & 0.94 & $<0.01$ \\
\hline Liocarcinus holsatus & -18.72 & NA & 11.78 & NA & $(-)$ & -18.29 & NA & 11.79 & NA & $<0.01$ \\
\hline Macropodia parva & - & - & - & - & - & -20.63 & 0.37 & 10.24 & 0.63 & $<0.01$ \\
\hline Melita palmata & -19.06 & 0.64 & 10.48 & 0.67 & 0.02 & -22.46 & 0.59 & 10.10 & 0.86 & $<0.01$ \\
\hline Palaemon serratus & -15.81 & 1.11 & 12.56 & 0.32 & $<0.01$ & -15.58 & 0.44 & 13.18 & 0.43 & $<0.01$ \\
\hline Porcellana platycheles* & -19.28 & 1.73 & 8.89 & 0.78 & 4.49 & -19.95 & 1.61 & 9.39 & 0.45 & 19.38 \\
\hline Processa edulis & -19.05 & NA & 11.92 & NA & $<0.01$ & - & - & - & - & - \\
\hline \multicolumn{11}{|l|}{ Bivalvia } \\
\hline Cerastoderma edule* & -18.23 & 0.45 & 9.96 & 0.08 & 0.01 & - & - & - & - & 0.03 \\
\hline Magallana gigas* & -18.03 & 0.54 & 10.51 & 0.68 & 31.95 & -18.82 & 0.73 & 10.57 & 0.65 & 49.21 \\
\hline $\begin{array}{l}\text { Mytilus } \text { cf. } \\
\text { galloprovincialis* }\end{array}$ & -18.97 & 1.03 & 9.14 & 0.76 & 0.19 & -19.63 & 0.75 & 9.22 & 0.46 & 1.06 \\
\hline Ostrea edulis* & -18.92 & NA & 10.00 & NA & 0.04 & -19.62 & NA & 10.29 & NA & 0.37 \\
\hline Polititapes rhomboides* & -20.60 & NA & 9.74 & NA & $<0.01$ & - & - & - & - & - \\
\hline Ruditapes philippinarum* & -18.33 & 0.28 & 9.80 & 0.30 & 0.04 & -18.37 & NA & 11.02 & NA & 0.22 \\
\hline Venerupis corrugata* & -19.09 & 1.10 & 9.88 & 0.60 & 0.03 & -20.46 & 1.01 & 9.94 & 0.55 & 0.39 \\
\hline \multicolumn{11}{|l|}{ Gastropoda } \\
\hline Crepidula fornicata* & -19.16 & 1.31 & 9.01 & 0.37 & 1.87 & -19.58 & 1.07 & 8.81 & 0.38 & 0.74 \\
\hline Gibbula tumida* & -15.80 & 1.34 & 11.57 & 1.12 & $(-)$ & - & - & - & - & - \\
\hline Littorina littorea* & -14.74 & 1.46 & 9.98 & 0.49 & 0.07 & -15.02 & 1.32 & 10.98 & 0.52 & 0.02 \\
\hline Nucella lapillus & -18.22 & 1.61 & 11.90 & 0.80 & 0.52 & -17.37 & 0.92 & 11.93 & 0.46 & 0.50 \\
\hline Ocenebra erinaceus & -16.20 & 0.37 & 11.11 & 0.78 & 0.03 & -16.78 & 0.96 & 11.47 & 0.52 & $<0.01$ \\
\hline Phorcus lineatus* & - & - & - & - & - & -14.51 & NA & 11.50 & NA & $<0.01$ \\
\hline Steromphala cineraria* & -13.65 & 0.30 & 10.94 & 0.96 & $<0.01$ & -15.66 & 0.71 & 11.92 & 0.23 & $<0.01$ \\
\hline Steromphala umbilicalis* & -13.90 & 0.72 & 10.68 & 0.56 & 0.31 & -13.91 & 0.58 & 11.22 & 0.48 & 0.35 \\
\hline Tritia reticulata & -15.15 & 0.68 & 11.72 & 0.66 & 0.01 & -15.16 & NA & 12.58 & NA & $<0.01$ \\
\hline \multicolumn{11}{|l|}{ Pycnogonida } \\
\hline Achelia echinata\# & -19.02 & 0.27 & 10.83 & 0.99 & $<0.01$ & - & - & - & - & - \\
\hline Achelia simplex\# & -18.97 & 0.23 & 10.73 & 0.24 & $<0.01$ & - & - & - & - & - \\
\hline Achelia spp.\# & - & - & - & - & - & -19.89 & 0.29 & 10.44 & 0.39 & 0.15 \\
\hline \multicolumn{11}{|l|}{ Anthozoa } \\
\hline Actinia equina & -15.47 & 0.66 & 12.44 & 0.79 & $(-)$ & -16.57 & 3.22 & 12.33 & 0.74 & 0.11 \\
\hline Anemonia viridis & -16.33 & NA & 14.88 & NA & $(-)$ & - & - & - & - & - \\
\hline Cereus pedunculatus & -15.76 & 0.50 & 12.30 & 1.27 & 0.34 & -16.30 & 1.40 & 12.66 & 0.39 & 0.35 \\
\hline \multicolumn{11}{|l|}{ Ascidiacea } \\
\hline Ascidia sp. ${ }^{*}$ & - & - & - & - & - & -21.31 & NA & 11.41 & NA & $(-)$ \\
\hline Molgula sp.* & - & - & - & - & - & -21.81 & 0.08 & 10.22 & 0.31 & $<0.01$ \\
\hline Polyclinum aurantium $*$ & -22.00 & NA & 9.35 & NA & 0.05 & - & - & - & - & - \\
\hline Styela clava* & - & - & - & - & 0.14 & -23.57 & 0.49 & 10.75 & 0.22 & 0.19 \\
\hline
\end{tabular}




\begin{tabular}{lcccccccccc}
\hline Other & & & & & & & & & & \\
\hline Bryozoa $^{*}$ & - & - & - & - & - & -20.59 & NA & 8.97 & NA & $(-)$ \\
\hline Collembola $^{*}$ & - & - & - & - & $<0.01$ & -14.27 & NA & 6.98 & NA & $<0.01$ \\
\hline Nematoda & -15.54 & 0.39 & 14.96 & 0.97 & $<0.01$ & -17.06 & 0.71 & 14.82 & 0.15 & 0.06 \\
\hline Nemerte & -16.58 & 0.93 & 12.69 & 0.50 & 0.20 & -15.40 & 0.85 & 12.69 & 0.37 & 0.25 \\
\hline Sipunculidea & & & & & & & & & & \\
\hline Golfingia elongata* & -15.41 & 0.56 & 10.24 & 0.85 & $<0.01$ & -16.21 & 0.26 & 11.42 & 0.72 & 0.02 \\
\hline Golfingia vulgaris* & -14.85 & 0.75 & 10.43 & 0.75 & 0.38 & -15.53 & 0.70 & 9.90 & 0.94 & 0.56 \\
\hline Nephasoma minutum* & - & - & - & - & 0.02 & -16.33 & 0.68 & 10.23 & 0.65 & 0.07 \\
\hline Actinopterygii & & & & & & & & & & \\
\hline Callionymus lyra & -16.37 & NA & 13.32 & NA & $(-)$ & -18.05 & NA & 13.14 & NA & $<0.01$ \\
\hline Ciliata mustela & -18.46 & 1.32 & 13.53 & 0.07 & $(-)$ & - & - & - & - & - \\
\hline $\begin{array}{l}\text { Hippocampus } \\
\text { hippocampus }\end{array}$ & -19.02 & NA & 14.28 & NA & $(-)$ & - & - & - & - & - \\
\hline Lipophrys pholis $($ ES $)$ & -17.36 & NA & 13.64 & NA & $(-)$ & -16.58 & 0.50 & 14.40 & 0.21 & 0.06 \\
\hline Liza aurata & -15.35 & 3.30 & 11.56 & 0.39 & $(-)$ & - & - & - & - & - \\
\hline Liza ramada & -13.98 & 1.54 & 11.16 & 0.06 & $(-)$ & - & - & - & - & - \\
\hline Pleuronectes platessa & -13.93 & NA & 12.52 & NA & $(-)$ & -15.42 & 1.02 & 12.15 & 0.31 & $<0.01$ \\
\hline Pomatoschistus sp. & -15.29 & 1.14 & 14.14 & 0.43 & $(-)$ & -16.19 & 0.57 & 13.97 & 0.42 & $<0.01$ \\
\hline Raja undulata & -16.88 & NA & 14.84 & NA & $(-)$ & - & - & - & - & - \\
\hline Scophthalmus rhombus & -16.41 & NA & 14.03 & NA & $(-)$ & - & - & - & - & - \\
\hline Solea vulgaris & -14.69 & 1.33 & 13.52 & 0.40 & $<0.01$ & -14.16 & 0.71 & 13.49 & 0.59 & $<0.01$ \\
\hline Trachinus vipera & -17.85 & NA & 13.13 & NA & $<0.01$ & - & - & - & - & - \\
\hline Trisopterus luscus & -18.30 & 0.11 & 14.21 & 0.13 & $<0.01$ & -15.99 & 0.76 & 15.18 & 0.50 & $<0.01$ \\
\hline & & & & & & & & & \\
\hline
\end{tabular}


Table S3. Estimated contributions of the two (control site) or three (Reef site) main food sources, particulate organic matter (POM), microphytobenthos (MPB) and green algae from the genus Ulva (ULV), for the primary consumers present in the control, associated (AS) and engineered (ES) sediments in winter (W) and summer (S) using the Stable Isotope Mixing Model in R (simmr). The mean contribution \pm the standard deviation of the mean contribution followed by the $97.5 \%$ confidence interval are indicated. The sum of the pelagic (POM) and benthic (MPB for the control site and MPB + ULV for the reef site) mean contributions is also indicated. The mixing model was run for species for which we had at least three replicate samples by sediment type and season, identified as $\mathrm{n}$ in the table. The species accounting for more than $1 \%$ of the total biomass in each sediment type (Sed) in winter and/or summer are designated by * for the CS and AS and \# for the ES.

\begin{tabular}{|c|c|c|c|c|c|c|c|c|c|c|c|c|c|}
\hline \multicolumn{5}{|c|}{ Control site } & \multicolumn{9}{|c|}{ Reef site } \\
\hline Species & $\mathbf{n}$ & Sea & $\begin{array}{l}\text { POM / } \\
\text { Pelagic }\end{array}$ & $\begin{array}{c}\text { MPB / } \\
\text { Benthic }\end{array}$ & Species & $\mathbf{n}$ & Sea & $\begin{array}{c}\text { Se } \\
\text { d }\end{array}$ & POM & MPB & ULV & Pelagic & Benthic \\
\hline \multirow[t]{2}{*}{ CEDU* } & 51 & $\mathrm{~W}$ & $\begin{array}{c}28.0 \pm 3.5 \\
(20.9-34.7)\end{array}$ & $\begin{array}{c}72.0 \pm 3.5 \\
(65.3-79.1)\end{array}$ & CEDU & 3 & $\mathrm{~W}$ & AS & $\begin{array}{c}29.3 \pm 14.8 \\
(5.3-62.6)\end{array}$ & $\begin{array}{c}44.9 \pm 19.7 \\
(8.4-81.8)\end{array}$ & $\begin{array}{c}25.8 \pm 13.7 \\
(4.8-56.8)\end{array}$ & 29.3 & 70.7 \\
\hline & 41 & $\mathrm{~S}$ & $\begin{array}{c}42.9 \pm 3.7 \\
(35.6-50.0)\end{array}$ & $\begin{array}{c}57.1 \pm 3.7 \\
(50.0-64.4)\end{array}$ & & 5 & $\mathrm{~S}$ & AS & $\begin{array}{l}53.6 \pm 10.2 \\
(30.5-72.1)\end{array}$ & $\begin{array}{c}26.2 \pm 12.9 \\
(5.2-55.5)\end{array}$ & $\begin{array}{l}20.2 \pm 8.1 \\
(5.3-37.0)\end{array}$ & 53.6 & 46.4 \\
\hline \multirow[t]{4}{*}{ CFOR } & 10 & $\mathrm{~W}$ & $\begin{array}{c}44.1 \pm 7.6 \\
(29.0-59.1)\end{array}$ & $\begin{array}{c}55.9 \pm 7.6 \\
(40.9-71.0)\end{array}$ & CFOR*\# & 39 & $\mathrm{~W}$ & AS & $\begin{array}{c}50.7 \pm 4.8 \\
(41.2-60.2)\end{array}$ & $\begin{array}{c}39.5 \pm 6.3 \\
(26.8-51.6)\end{array}$ & $\begin{array}{c}9.8 \pm 3.3 \\
(3.5-16.5)\end{array}$ & 50.7 & 49.3 \\
\hline & & & & & & 47 & W & $\mathrm{ES}$ & $\begin{array}{c}47.4 \pm 3.5 \\
(40.3-54.2)\end{array}$ & $\begin{array}{c}45.3 \pm 4.9 \\
(35.4-54.7)\end{array}$ & $\begin{array}{c}7.3 \pm 2.7 \\
(2.6-13.1)\end{array}$ & 47.4 & 52.6 \\
\hline & & & & & & 47 & $\mathrm{~S}$ & AS & $\begin{array}{c}56.7 \pm 3.8 \\
(49.3-64.1)\end{array}$ & $\begin{array}{c}38.4 \pm 4.7 \\
(28.8-47.3)\end{array}$ & $\begin{array}{c}4.9 \pm 2.3 \\
(1.2-10.0)\end{array}$ & 56.7 & 43.3 \\
\hline & & & & & & 38 & $\mathrm{~S}$ & $\mathrm{ES}$ & $\begin{array}{c}54.6 \pm 3.7 \\
(47.3-61.8)\end{array}$ & $\begin{array}{c}40.1 \pm 4.9 \\
(30.0-49.2)\end{array}$ & $\begin{array}{c}5.3 \pm 2.4 \\
(1.5-10.7)\end{array}$ & 54.6 & 45.4 \\
\hline $\mathrm{LCON}^{*}$ & 4 & W & $\begin{array}{c}23.9 \pm 14.3 \\
(3.7-59.7)\end{array}$ & $\begin{array}{l}76.1 \pm 14.3 \\
(40.3-96.3)\end{array}$ & LCON & & & & & & & & \\
\hline
\end{tabular}




\begin{tabular}{|c|c|c|c|c|c|c|c|c|c|c|c|c|c|}
\hline & 6 & $\mathrm{~S}$ & $\begin{array}{l}16.5 \pm 9.3 \\
(2.9-37.2)\end{array}$ & $\begin{array}{c}83.5 \pm 9.3 \\
(62.8-97.1)\end{array}$ & & 3 & $\mathrm{~S}$ & AS & $\begin{array}{c}22.5 \pm 10.3 \\
(5.0-44.0)\end{array}$ & $\begin{array}{c}24.9 \pm 15.8 \\
(3.4-65.4)\end{array}$ & $\begin{array}{l}52.6 \pm 14.7 \\
(17.4-78.2)\end{array}$ & 22.5 & 77.5 \\
\hline \multirow[t]{4}{*}{ LLEV } & 3 & $\mathrm{~W}$ & $\begin{array}{c}40.9 \pm 24.8 \\
(4.7-90.6)\end{array}$ & $\begin{array}{c}59.1 \pm 24.8 \\
(9.4-95.3)\end{array}$ & LLEV & 10 & $\mathrm{~W}$ & AS & $\begin{array}{c}21.9 \pm 10.7 \\
(3.9-44.3)\end{array}$ & $\begin{array}{l}68.6 \pm 14.9 \\
(33.6-91.9)\end{array}$ & $\begin{array}{c}9.5 \pm 7.7 \\
(1.2-29.8)\end{array}$ & 21.9 & 78.1 \\
\hline & & & & & & 26 & $\mathrm{~W}$ & $\mathrm{ES}$ & $\begin{array}{c}38.2 \pm 6.5 \\
(25.3-51.0)\end{array}$ & $\begin{array}{c}56.6 \pm 8.2 \\
(38.5-71.5)\end{array}$ & $\begin{array}{c}5.2 \pm 3.6 \\
(0.9-14.4)\end{array}$ & 38.2 & 61.8 \\
\hline & 3 & $\mathrm{~S}$ & $\begin{array}{c}34.2 \pm 24.7 \\
(3.0-88.7)\end{array}$ & $\begin{array}{l}65.8 \pm 24.7 \\
(11.3-97.0)\end{array}$ & & 5 & $\mathrm{~S}$ & AS & $\begin{array}{l}41.9 \pm 14.2 \\
(11.2-69.8)\end{array}$ & $\begin{array}{c}38.9 \pm 19.3 \\
(6.4-78.9)\end{array}$ & $\begin{array}{c}19.2 \pm 12.1 \\
(2.7-46.2)\end{array}$ & 41.9 & 58.1 \\
\hline & & & & & & 19 & $\mathrm{~S}$ & $\mathrm{ES}$ & $\begin{array}{c}56.7 \pm 9.0 \\
(39.2-74.7)\end{array}$ & $\begin{array}{l}37.6 \pm 10.3 \\
(16.6-56.7)\end{array}$ & $\begin{array}{c}5.7 \pm 3.9 \\
(1.0-15.7)\end{array}$ & 56.7 & 43.3 \\
\hline \multirow[t]{2}{*}{ LBAL* } & 45 & $\mathrm{~W}$ & $\begin{array}{l}2.8 \pm 1.6 \\
(0.6-6.7)\end{array}$ & $\begin{array}{c}97.2 \pm 1.6 \\
(93.9-99.4)\end{array}$ & LBAL & & & & & & & & \\
\hline & 37 & $\mathrm{~S}$ & $\begin{array}{l}3.6 \pm 2.1 \\
(0.7-8.5)\end{array}$ & $\begin{array}{c}96.4 \pm 2.1 \\
(91.5-99.3)\end{array}$ & & 5 & $\mathrm{~S}$ & AS & $\begin{array}{l}12.9 \pm 9.7 \\
(2.0-39.8)\end{array}$ & $\begin{array}{l}62.5 \pm 18.2 \\
(18.8-90.1)\end{array}$ & $\begin{array}{c}24.6 \pm 16.1 \\
(3.7-68.0)\end{array}$ & 12.9 & 87.1 \\
\hline \multirow[t]{3}{*}{ McfGAL } & 21 & $\mathrm{~W}$ & $\begin{array}{c}54.6 \pm 4.9 \\
(45.6-64.3) \\
\end{array}$ & $\begin{array}{c}45.4 \pm 4.9 \\
(35.7-54.4)\end{array}$ & McfGAL\# & 4 & $\mathrm{~W}$ & AS & $\begin{array}{l}46.1 \pm 12.2 \\
(17.9-69.3)\end{array}$ & $\begin{array}{c}33.1 \pm 15.5 \\
(6.2-67.3)\end{array}$ & $\begin{array}{l}20.8 \pm 9.3 \\
(4.6-40.2)\end{array}$ & 46.1 & 53.9 \\
\hline & & & & & & 33 & $\mathrm{~W}$ & $\mathrm{ES}$ & $\begin{array}{c}46.5 \pm 4.1 \\
(38.5-54.3)\end{array}$ & $\begin{array}{c}43.3 \pm 6.2 \\
(30.7-55.0)\end{array}$ & $\begin{array}{l}10.2 \pm 3.6 \\
(3.5-17.7)\end{array}$ & 46.5 & 53.5 \\
\hline & 8 & $\mathrm{~S}$ & $\begin{array}{c}58.9 \pm 8.7 \\
(41.0-75.8)\end{array}$ & $\begin{array}{c}41.1 \pm 8.7 \\
(24.2-59.0)\end{array}$ & & 26 & $\mathrm{~S}$ & $\mathrm{ES}$ & $\begin{array}{c}56.7 \pm 4.0 \\
(48.9-64.5)\end{array}$ & $\begin{array}{c}30.6 \pm 6.4 \\
(17.9-42.8)\end{array}$ & $\begin{array}{l}12.7 \pm 4.0 \\
(5.2-20.7)\end{array}$ & 56.7 & 43.3 \\
\hline \multirow[t]{3}{*}{ RPHI } & 3 & $\mathrm{~W}$ & $\begin{array}{l}44.9 \pm 17.1 \\
(10.8-79.9)\end{array}$ & $\begin{array}{l}55.1 \pm 17.1 \\
(20.1-89.2)\end{array}$ & RPHI* & 5 & $\mathrm{~W}$ & AS & $\begin{array}{l}41.0 \pm 10.2 \\
(18.8-60.5)\end{array}$ & $\begin{array}{c}35.5 \pm 14.6 \\
(8.9-66.1)\end{array}$ & $\begin{array}{l}23.5 \pm 9.0 \\
(6.8-41.6)\end{array}$ & 41 & 59 \\
\hline & & & & & & 3 & $\mathrm{~W}$ & $\mathrm{ES}$ & $\begin{array}{c}37.1 \pm 13.6 \\
(9.5-63.1)\end{array}$ & $\begin{array}{c}35.2 \pm 17.8 \\
(5.7-73.5)\end{array}$ & $\begin{array}{c}27.7 \pm 11.9 \\
(5.9-51.9)\end{array}$ & 37.1 & 62.9 \\
\hline & 6 & $\mathrm{~S}$ & $\begin{array}{l}54.1 \pm 10.5 \\
(32.5-74.5) \\
\end{array}$ & $\begin{array}{l}45.9 \pm 10.5 \\
(25.5-67.5)\end{array}$ & & 14 & $\mathrm{~S}$ & AS & $\begin{array}{c}63.7 \pm 5.5 \\
(52.4-74.4)\end{array}$ & $\begin{array}{l}19.5 \pm 8.2 \\
(5.0-36.4)\end{array}$ & $\begin{array}{l}16.8 \pm 5.6 \\
(5.9-27.6)\end{array}$ & 63.7 & 36.3 \\
\hline \multirow[t]{2}{*}{ SSOL } & & & & & SSOL & 11 & W & AS & $\begin{array}{c}24.3 \pm 6.5 \\
(10.8-36.4)\end{array}$ & $\begin{array}{c}58.7 \pm 9.6 \\
(40.1-77.3)\end{array}$ & $\begin{array}{l}17.0 \pm 6.3 \\
(5.2-30.2)\end{array}$ & 24.3 & 75.7 \\
\hline & 11 & $\mathrm{~S}$ & $\begin{array}{c}32.7 \pm 7.5 \\
(17.4-47.1)\end{array}$ & $\begin{array}{c}67.3 \pm 7.5 \\
(52.9-82.6)\end{array}$ & & 5 & $\mathrm{~S}$ & AS & $\begin{array}{c}38 \pm 12.0 \\
(12.8-61.0)\end{array}$ & $\begin{array}{l}45.5 \pm 15.8 \\
(13.7-75.7)\end{array}$ & $\begin{array}{l}16.5 \pm 8.4 \\
(3.4-36.1)\end{array}$ & 38 & 62 \\
\hline
\end{tabular}




\begin{tabular}{|c|c|c|c|c|c|c|c|c|c|c|c|c|c|}
\hline VCOR & 4 & W & $\begin{array}{l}42.6 \pm 14.7 \\
(13.4-73.6)\end{array}$ & $\begin{array}{l}57.4 \pm 14.7 \\
(26.4-86.6)\end{array}$ & VCOR* & 8 & W & AS & $\begin{array}{l}40.6 \pm 10.3 \\
(19.3-59.8)\end{array}$ & $\begin{array}{l}39.7 \pm 14.0 \\
(12.7-67.7)\end{array}$ & $\begin{array}{l}19.7 \pm 7.7 \\
(6.0-35.7)\end{array}$ & 40.6 & 59.4 \\
\hline & & & & & & 12 & $\mathrm{~W}$ & ES & $\begin{array}{c}51.3 \pm 6.3 \\
(38.0-62.5)\end{array}$ & $\begin{array}{l}22.1 \pm 9.4 \\
(5.8-42.2)\end{array}$ & $\begin{array}{c}26.6 \pm 6.3 \\
(13.8-38.6)\end{array}$ & 51.3 & 48.7 \\
\hline & 4 & $\mathrm{~S}$ & $\begin{array}{l}59.1 \pm 14.9 \\
(26.0-87.3)\end{array}$ & $\begin{array}{l}40.9 \pm 14.9 \\
(12.7-74.0)\end{array}$ & & 4 & $S$ & AS & $\begin{array}{l}54.8 \pm 13.5 \\
(21.3-77.8)\end{array}$ & $\begin{array}{c}25.1 \pm 14.5 \\
(4.2-59.9)\end{array}$ & $\begin{array}{l}20.1 \pm 9.4 \\
(4.5-40.1)\end{array}$ & 54.8 & 45.2 \\
\hline & & & & & & 23 & $\mathrm{~S}$ & $\mathrm{ES}$ & $\begin{array}{c}70.3 \pm 3.9 \\
(62.1-77.6)\end{array}$ & $\begin{array}{c}8.7 \pm 4.7 \\
(1.8-19.5)\end{array}$ & $\begin{array}{c}21.0 \pm 4.1 \\
(12.4-28.7)\end{array}$ & 70.3 & 29.7 \\
\hline \multirow[t]{2}{*}{ AALB } & 9 & W & $\begin{array}{l}12.7 \pm 7.3 \\
(2.4-30.2)\end{array}$ & $\begin{array}{c}87.3 \pm 7.3 \\
(69.8-97.6)\end{array}$ & ACHspp & 9 & W & ES & $\begin{array}{c}49.5 \pm 5.5 \\
(38.6-59.8)\end{array}$ & $\begin{array}{l}12.1 \pm 7.4 \\
(2.2-30.7)\end{array}$ & $\begin{array}{c}38.4 \pm 6.6 \\
(23.5-49.9)\end{array}$ & 49.5 & 50.5 \\
\hline & 9 & S & $\begin{array}{l}14.4 \pm 7.3 \\
(2.9-31.2)\end{array}$ & $\begin{array}{c}85.6 \pm 7.3 \\
(68.8-97.1)\end{array}$ & & 8 & $\mathrm{~S}$ & ES & $\begin{array}{c}59.4 \pm 6.9 \\
(43.8-71.7)\end{array}$ & $\begin{array}{l}12.5 \pm 7.5 \\
(2.3-30.4)\end{array}$ & $\begin{array}{c}28.1 \pm 6.9 \\
(13.4-40.9)\end{array}$ & 59.4 & 40.6 \\
\hline CALA & 4 & $\mathrm{~W}$ & $\begin{array}{c}26.2 \pm 14.8 \\
(4.6-63.9)\end{array}$ & $\begin{array}{l}73.8 \pm 14.8 \\
(36.1-95.4)\end{array}$ & CTEN* & 3 & $\mathrm{~W}$ & AS & $\begin{array}{c}21.7 \pm 10.8 \\
(4.6-46.0)\end{array}$ & $\begin{array}{c}33.7 \pm 17.2 \\
(5.9-71.8)\end{array}$ & $\begin{array}{l}44.6 \pm 14.8 \\
(14.2-72.8)\end{array}$ & 21.7 & 78.3 \\
\hline GZAD & 6 & $\mathrm{~W}$ & $\begin{array}{l}56.8 \pm 10.5 \\
(36.0-77.5)\end{array}$ & $\begin{array}{l}43.2 \pm 10.5 \\
(22.5-64.0)\end{array}$ & & 8 & $\mathrm{~S}$ & AS & $\begin{array}{c}42.8 \pm 7.5 \\
(25.1-55.7)\end{array}$ & $\begin{array}{c}14.2 \pm 10.5 \\
(2.0-42.2)\end{array}$ & $\begin{array}{l}43.0 \pm 10.5 \\
(20.2-62.0)\end{array}$ & 42.8 & 57.2 \\
\hline \multirow[t]{2}{*}{ MTEN } & 12 & $\mathrm{~W}$ & $\begin{array}{c}8.2 \pm 5.2 \\
(1.4-20.9)\end{array}$ & $\begin{array}{c}91.8 \pm 5.2 \\
(79.1-98.6)\end{array}$ & CVOL & 3 & $\mathrm{~W}$ & ES & $\begin{array}{c}36.4 \pm 16.8 \\
(6.8-72.4)\end{array}$ & $\begin{array}{c}39.8 \pm 21.6 \\
(5.4-83.7)\end{array}$ & $\begin{array}{c}23.8 \pm 15.8 \\
(2.8-59.4)\end{array}$ & 36.4 & 63.6 \\
\hline & 9 & $\mathrm{~S}$ & $\begin{array}{l}10.6 \pm 7.1 \\
(1.8-28.3)\end{array}$ & $\begin{array}{c}89.4 \pm 7.1 \\
(71.7-98.2)\end{array}$ & & 5 & $S$ & ES & $\begin{array}{l}41.8 \pm 12.1 \\
(14.7-66.1)\end{array}$ & $\begin{array}{c}39.2 \pm 17.9 \\
(6.7-76.5)\end{array}$ & $\begin{array}{c}19.0 \pm 11.7 \\
(2.4-44.6)\end{array}$ & 41.8 & 58.2 \\
\hline NLAT & 3 & $\mathrm{~W}$ & $\begin{array}{c}26.8 \pm 19.1 \\
(3.5-78.5)\end{array}$ & $\begin{array}{l}73.2 \pm 19.1 \\
(21.5-96.5)\end{array}$ & SUMB & 35 & $\mathrm{~W}$ & $\mathrm{ES}$ & $\begin{array}{l}3.2 \pm 2.0 \\
(0.6-8.2)\end{array}$ & $\begin{array}{c}41.7 \pm 4.9 \\
(31.6-50.7)\end{array}$ & $\begin{array}{c}55.1 \pm 4.6 \\
(46.5-64.8)\end{array}$ & 3.2 & 96.8 \\
\hline \multirow[t]{2}{*}{ SARM } & 3 & $\mathrm{~W}$ & $\begin{array}{c}27.9 \pm 22.6 \\
(2.7-86.4)\end{array}$ & $\begin{array}{l}72.1 \pm 22.6 \\
(13.6-97.3)\end{array}$ & & 30 & $\mathrm{~S}$ & $\mathrm{ES}$ & $\begin{array}{l}2.8 \pm 1.8 \\
(0.5-7.5)\end{array}$ & $\begin{array}{c}25.6 \pm 6.3 \\
(12.0-36.6)\end{array}$ & $\begin{array}{c}71.6 \pm 6.2 \\
(60.7-85.5)\end{array}$ & 2.8 & 97.2 \\
\hline & 3 & $\mathrm{~S}$ & $\begin{array}{c}26.8 \pm 21.0 \\
(3.1-82.5)\end{array}$ & $\begin{array}{l}73.2 \pm 21.0 \\
(17.5-96.9)\end{array}$ & GVUL\# & 16 & $\mathrm{~W}$ & $\mathrm{ES}$ & $\begin{array}{c}4.1 \pm 2.7 \\
(0.8-11.0)\end{array}$ & $\begin{array}{c}42.7 \pm 8.8 \\
(23.1-58.7)\end{array}$ & $\begin{array}{c}53.2 \pm 8.5 \\
(38.0-72.0)\end{array}$ & 4.1 & 95.9 \\
\hline \multirow[t]{2}{*}{ UROsp } & 4 & $\mathrm{~W}$ & $\begin{array}{c}20.8 \pm 18.9 \\
(2.1-74.3)\end{array}$ & $\begin{array}{l}79.2 \pm 18.9 \\
(25.7-97.9)\end{array}$ & & 18 & $\mathrm{~S}$ & $\mathrm{ES}$ & $\begin{array}{c}4.4 \pm 2.3 \\
(1.0-10.0)\end{array}$ & $\begin{array}{c}56.1 \pm 9.0 \\
(36.1-71.8)\end{array}$ & $\begin{array}{c}39.5 \pm 8.5 \\
(24.5-58.4)\end{array}$ & 4.4 & 95.6 \\
\hline & 4 & $\mathrm{~S}$ & $\begin{array}{c}23.3 \pm 19.7 \\
(2.4-78.1)\end{array}$ & $\begin{array}{l}76.7 \pm 19.7 \\
(21.9-97.6)\end{array}$ & LLIT & 13 & $\mathrm{~W}$ & $\mathrm{ES}$ & $\begin{array}{c}9.3 \pm 6.6 \\
(1.5-26.4)\end{array}$ & $\begin{array}{c}55.8 \pm 9.4 \\
(35.5-72.9)\end{array}$ & $\begin{array}{c}34.9 \pm 7.1 \\
(21.2-49.2)\end{array}$ & 9.3 & 90.7 \\
\hline
\end{tabular}




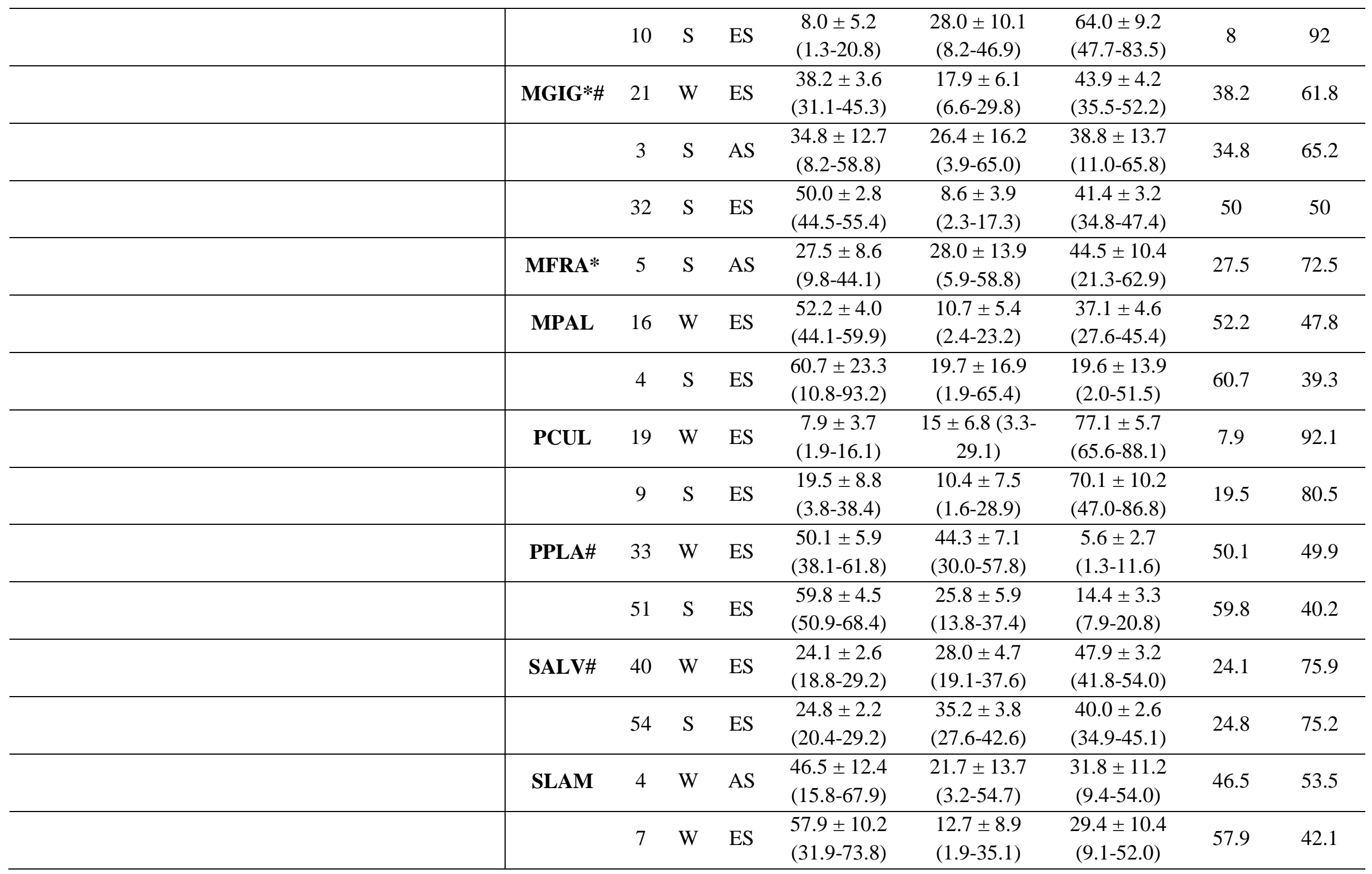




\begin{tabular}{l|llllllll}
\hline & \multirow{2}{*}{3} & S & AS & $\begin{array}{c}49.2 \pm 21.2 \\
(7.4-83.1)\end{array}$ & $\begin{array}{c}22.3 \pm 15.9 \\
(2.7-63.8)\end{array}$ & $\begin{array}{c}28.5 \pm 16.7 \\
(3.7-65.3)\end{array}$ & $\begin{array}{c}49.2 \\
50.8\end{array}$ \\
\hline
\end{tabular}

Sea: season, CEDU: Cerastoderma edule, CFOR: Crepidula fornicata, LCON: Lanice conchilega, LLEV: Lekanesphaera levii, LBAL: Limecola balthica, McfGAL: Mytilus cf. galloprovincialis, RPHI: Ruditapes philippinarum, SSOL: Spisula solida, VCOR: Venerupis corrugata, AALB: Abra alba, CALA: Caulleriella alata, GZAD: Gammarus zaddachi, MTEN: Macomangulus tenuis, NLAT: Notomastus latericeus, SARM: Scoloplos armiger, UROsp: Urothoe sp., ACHspp: Achelia spp., CTEN: Cirriformia tentaculata, CVOL: Corophium volutator, SUMB: Steromphala umbilicalis, GVUL: Golfingia vulgaris, LLIT: Littorina littorea, MGIG: Magallana gigas, MFRA: Mediomastus fragilis, MPAL: Melita palmata, PCUL: Perinereis cultrifera, PPLA: Porcellana platycheles, SALV: Sabellaria alveolata, SLAM: Spirobranchus lamarckii. 
